Article

\title{
City Branding, Sustainable Urban Development and the Rentier State. How Do Qatar, Abu Dhabi and Dubai Present Themselves in the Age of Post Oil and Global Warming?
}

\author{
Martin De Jong ${ }^{1,2}$, Thomas Hoppe ${ }^{3}$ and Negar Noori ${ }^{1, *}$ \\ 1 Erasmus School of Law and Rotterdam School of Management, Erasmus University Rotterdam, \\ 3062 Rotterdam, The Netherlands; w.m.jong@law.eur.nl \\ 2 School of International Relations and Public Affairs, Fudan University, Shanghai 200433, China \\ 3 Faculty of Technology, Policy \& Management, Delft University of Technology, 2628 CD Delft, \\ The Netherlands; T.Hoppe@tudelft.nl \\ * Correspondence: noori@law.eur.nl; Tel.: +31-010-408-1510
}

Received: 4 April 2019; Accepted: 27 April 2019; Published: 30 April 2019

\begin{abstract}
In the past three decades Qatar, Abu Dhabi and Dubai have realised a meteoric economic rise. Whereas the former two can be considered 'rentier states' heavily depending on oil (and gas) revenues, the latter only leans on oil for a mere $6 \%$ of its gross domestic product (GDP). Although the economic rise has brought considerable welfare, it has also led these emirates to attain the world's highest per capita carbon footprint. To address this problem Qatar, Abu Dhabi and Dubai seem to have formulated policies with regard to sustainable urbanisation and adopted strong branding strategies to promote them internally and externally. In this paper we examine which steps have been taken to substantiate their claims to sustainable urbanisation, in branding as well as in actions taken towards implementation. We find that all three have been very active in branding their sustainable urbanisation policies, through visions and policy frameworks as well as prestigious development projects, but that the former is substantially more impressive than the latter. Results also show there is a difference between Abu Dhabi and Qatar on the one hand, and Dubai on the other. Dubai has large number of small 'free economic zones', academic institutions for developing a knowledge economy, and smart and/or sustainable urban neighbourhoods, while Qatar and Abu Dhabi have a small number of very large ones. From the three, it is currently Dubai which has taken the lead in this development, largely completing its industrial transition with vast economic diversification and urban expansion. However, across the board this has had little effect on its ecological footprint.
\end{abstract}

Keywords: city branding; sustainable urban development; rentier state; Qatar; emirates

\section{Introduction}

In the past three decades, a number of tiny gulf-states have realized a meteoric economic rise that very few analysts would have deemed possible [1-3]. Qatar, Abu Dhabi and Dubai were all emirates with population numbers well below 100,000 inhabitants whose prosperity depended heavily on rapidly declining revenue from pearl trading. When the British gave up their military protection in 1971, their independence hinged on a combination of decentralised unification and diplomatic agility [4-7]. Whereas Abu Dhabi and Dubai established an initially inconvenient federal arrangement with five other smaller emirates to their North-East (Sharjah, Ajman, Ras al-Khaimah, Umm al-Quwain and Fujairah) named the United Arab Emirates (UAE), Qatar and its tiny neighbour Bahrain maintained their independence and manoeuvred between regional superpowers Iran and Saudi Arabia, as well as 
each other [8]. As amply noted in the academic literature, the evolution of Qatar, Abu Dhabi and Dubai into global economic hubs by the year 2020, wielding considerable political and economic influence was something virtually nobody had anticipated. A superficial reading of their fate might have led one to conclude that it was primarily the exploration of oil and gas that had boosted their luck, but a closer look reveals that this is only true for Qatar and Abu Dhabi, but not for Dubai which leans on oil for a mere $6 \%$ of its GDP [3,9]. In many other emirates in fact, existing reserves have been largely depleted or even barely any oil was found. But even where large reserves were found, smart long-term oriented use of the cash-flow derived from it was used to set up immense sovereign wealth funds with substantial economic impact, nationally and internationally [10].

In fact, a much more credible explanation for their success has been a combination of personal, visionary and determined autocratic leadership in absolute monarchies, prudent, daring and diversified investment policies and skillful branding activities based on the revenues earned through oil and gas [11]. It is typically these features that differentiate them from Kuwait, which acquired its independence from Britain at an earlier stage and was far more developed at that time. The latter of the three partial explanations, branding, took the shape of constructing modern infrastructure hubs such as hypermodern ports and airports, establishing world-class airlines, developing landmark office towers, museums and shrines, offering homes to the wealthy and famous on iconic areas obtained through land reclamation, staging stunning world events like large exhibitions and sports championships, and boosting a powerful tourist industry by offering luxury resorts that lean on sea, sun, sand, camels and an expanding assortment of sophisticated and extreme shopping malls, and entertainment parks $[9,12-14]$.

Visionary leadership, prudent, diversified investment policies and skillful branding gave Qatar, Abu Dhabi and Dubai a substantial amount of soft power, and has led them to occupy top positions on the international rankings for GDP per capita [6,15-17]. Moreover, the populations of these three giants have expanded from a few dozen thousands in the 1970s to a few million each by 2020. The percentages of foreign workforce in their economies have risen from virtually none to over $80 \%$ in each. The figures in the other emirates are significantly lower, but there too GDP per capita, population and percentage of imported workers have witnessed a dramatic increase [15,18].

In spite of this enormous growth and the credit they take for these achievements, policy-makers and analysts in each of the three emirates have gradually come to realise that there are significant drawbacks to this success story. Domestic consumption has expanded rapidly to the detriment of people's health and the natural environment. Excessive wealth has detracted from their eagerness to work hard to succeed. Growing populations have made locals largely invisible in public spaces and increasingly worried about the control they have over their own societies. Enhanced global ambitions and visibility have made Qatar, Abu Dhabi and Dubai vulnerable to international criticism of the way gender equality and the labour conditions of poor workers are handled. Last but not least, shrinking energy reserves have all pushed them to reconsider their model of (economic) development $[3-5,10,15,16,19]$. Qatar, Abu Dhabi and Dubai have formulated policies that aim at preparing for a post-oil economy characterized by a diversification of their industrial activities and preservation of their natural environment. They have opened a number of free trade zones to facilitate foreign direct investment and international trading, introduced elements of common law to strengthen rule of law in business operations and welcomed leading universities and research centres in 'education

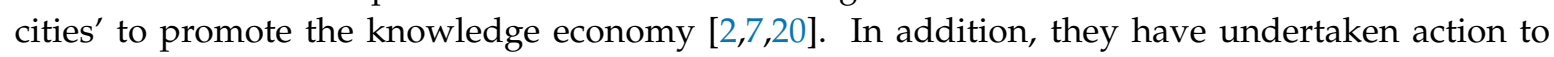
strengthen environmental protection, promote the development of renewable energy and in the long run reduce carbon emissions.

As could be expected, they have chosen to do so through a plethora of charming international branding initiatives of which Qatar's 'Lusail Smart City', Abu Dhabi's 'Masdar City' and Dubai's 'Media City' and 'Internet City' have perhaps received the greatest international media coverage [3,11,21], although signs reveal that stakeholder approval is mixed [22]. The attraction of investment start-ups meets difficulties, and population numbers are surprisingly low [23]. While official government sources 
tend to be confident that they can replicate their previous economic success in the environmental realm and keep their societies stable, many international (primarily Western) academics are surprised or dismayed at the low degree of domestic stakeholder involvement in rolling out these policies. Some have predicted in a variety of ways that the regimes behind these 'rentier states' will barely, or not at all prove capable of the necessary reforms, or are even at risk of collapse $[3,4,10,15,18]$. Neither of these two extremes have actually happened (yet). Energy consumption and carbon footprints are still among the highest in the world while the political and administrative leadership and elites are also still firmly in place.

In this contribution, we examine what effective policy initiatives loom behind the shiny branding practices regarding economic diversification and sustainable urbanization. In particularly we are interested in answering the question: Which steps have been taken to substantiate Qatar, Abu Dhabi and Dubai's claims to economic and ecological modernization? In answering this question, we will not be leaning explicitly on theories or methodologies as developed in the field of place branding, as we have done in previous work [24-26], but rather take publications in the field of political science and international relations related to the three emirates under study, more specifically the concept of the 'rentier state' and its impact on the branding and implementation of policies regarding sustainable urbanisation as the starting point of our analysis.

The next few sections will offer the following content. Section 2 will present a gist of the existing theories and insights on the topic, mostly taken from scholarly work in political science and international relations. This work has a strong focus on the concept of city branding, institutional arrangements, branding and policy-making in the emirates and has been produced by European, American and Iranian academics and analysts often having one leg in Qatar, Abu Dhabi or Dubai (Arab authors are conspicuously missing from the literature). We analyse the dominant argumentation in this literature and assess the validity of their occasional extreme optimism about enhanced political and economic empowerment of common citizens and otherwise disheartening pessimism when it comes to the social and environmental sustainability underlying this growth and the resilience of the regimes in place. In Section 3, we connect this body of theory with our research design and provide information on data collection and analysis. Section 4 presents an overview of the basic ideas and assumptions underlying the branding practices and policy initiatives on sustainable urbanization in the three emirates, including the national visions, plans, frameworks and online texts and videos in the three emirates. Section 5 demonstrates branding strategies and policy initiatives undertaken in Dubai, Abu Dhabi and Qatar to diversify their economies in free economic zones, boost their research and higher education systems in academic cities, and given impetus to sustainable urban development in smart and/or sustainable cities. In Section 6, we compare the three emirates in how they deal with branding and investing in sustainable urban development overall and discuss the implications of our findings for the future credibility and resilience of the 'rentier states'.

\section{The Politics of Branding and Sustainable Urban Development in Qatar, Abu Dhabi and Dubai}

\subsection{The Concept of City Branding}

By 'branding' we mean the practice of place, which can be seen as a long-term strategic activity $[27,28]$ aimed at the positioning of cities, regions and countries amidst their neighbours and peers, which is closely connected to the concept of 'place brand'. The latter can be defined as "a network of associations in the place consumers' minds based on the visual, verbal, and behavioral expression of a place and its' stakeholders. These associations differ in their influence within the network, and in importance for the placement of consumers' attitudes and behaviours." [29]. In relation to the city brand, 'place branding' can be seen as a strategic activity with cities trying to garner positive associations in the consumer's mind (Ibid.). City branding can also be seen as a holistic activity with city marketing and city promotion as contributing elements [30]. Lu and De Jong (2017) view city branding strategy as the practice of conveying a brand or symbolic essence of a nation, region or 
city to target audiences for enhancing one's fame and reputation or otherwise obtaining strategic gain [31]. 'City branding' then pertains to a communication system that connects the overall image and identity of a city [32,33]. According to Baker (2007) city branding, the image and identity of a given city are essential in making it unique among various alternatives [34]. Dinnie (2010) even argues that public authorities see a direct relation between the image of their city and its attractiveness as a place to attend, to live in, to invest in, or to study [12]. Others argue that current city factors address the city brand and city branding activities themselves. For instance, Anholt (2016) distinguishes a set of factors (image, identity, places, the position of city, suitable location, capacity and vitality of people) that influence the brand a given city adopts [35]. Shirvani Dastgerdi and De Luca (2019) developed a research model that addresses this issue, coining economic performance, media and advertising, cultural activities, policy making and urban planning as factors influencing city image, and indirectly city branding [36]. For the latter, the authors discern objectives such as creating global uniqueness, meaningfulness and acceptability, justifiable identity, stakeholder satisfaction, attracting resources and increasing the general wellbeing of citizens.

In practice, establishing a place branding strategy is often driven top-down by public administrators and materialized in a narrow-scope set of communication tactics to appeal to external, resourceful stakeholders [37]. City branding only seldom deploys the involvement of local citizens and stakeholders [29]. In acknowledging this problem Kavaratzis and Kalandides (2015) propose a rethinking of place brands by (i) incorporating more geographical understanding into place branding, and (ii) outlining a process that allows place elements and place-based associations to combine and form a place brand [38]. In a similar vein, Pedeliento \& Kavaratzis (2019) argue that developing place brands cannot be devised as a top-down agenda designed by public administrators in which strategic objectives are imposed on local stakeholders [39]. Rather, they argue that place branding strategy must be pursued with the involvement of stakeholders in setting strategic objectives, and by raising awareness that achieving these objectives is largely owed to their own practices. Pedeliento \& Kavaratzis (2019) argue that city branding is presumably more trustworthy, legitimate and effective once geographical and situational aspects are sufficiently addressed and setting the branding strategy and its objectives is not merely a top down endeavour, but also includes involvement of local stakeholders and citizenry [39]. As we will see below, not all of these aspects of city branding practices as advocated in the literature can be deemed common in gulf states.

\subsection{City Branding in Qatar, Abu Dhabi and Dubai}

"Be the flame, not the moth. You are the strength, you are the power, you are the decider, you are the thinker, you are the motivation, you are the reason, you are the purpose. Never forget that you are a brand [40]."

On August 10th 2018, Sara al Madani, (serial entrepreneur, public speaker, Board Member at the Sharjah Chamber of Commerce and Industry, Board Member at the UAE SME enterprise council of the Ministry of Economy, Board Member at ShjSEEN, and investor) posted the above message on LinkedIn. It epitomises the enormous drive among elites in wealthier gulf-states for a strong public profile, in social media as elsewhere. It has made Qatar, Abu Dhabi and Dubai world famous in recent decades and it is also beginning to affect other emirates such as Sharjah. Much of the academic work on the policy and politics of branding in the various emirates and its local, national and global impact has however been written by academics and journalists from outside the Arab world. Many of them have worked at universities in Qatar, Abu Dhabi and Dubai and subsequently moved on to other parts of the world. They all stress how important branding and public diplomacy have been in attracting foreign direct investment, tourism, business opportunities, qualified expatriate employees and international goodwill and how skilfully they were used. They are unanimous in their acclaim of what these gulf-states have achieved in terms of economic growth and global fame, and highlight how the leadership in these countries has shown vision and courage to think long term, undertake occasionally 
risky development projects and utilized generous revenues from oil and gas for strengthening their financial profile, growing a variety of industrial sectors and their own attractiveness.

But this academic praise is not unqualified. While some see in the positioning of the wealthier emirates a tendency to overemphasize Bedouin features at the expense of Persian and other elements in branding, their canonised national history and culture [6,20], others point at the large number of remaining severe social and policy issues the young and wealthy states are still faced with $[3-5,15,18]$. A very prominent challenge is the environmental one. The native population resident in the emirates, and that in the UAE and Qatar in particular, are the most resource intense consumers in the world. Their high levels of income and plentiful availability of natural resources make it almost natural for them to use large amounts of (their own) energy and import massive amounts of other products not readily available in the desert. Moreover, ambitious development programmes in land reclamation, real estate, infrastructure development, tourism, entertainment and post-oil heavy manufacturing industries also drive up the use of both natural resources and carbon emissions.

Mari Luomi (2012) was the first to examine the proclaimed shift in environmental policies in the emirates in response to their negative public image in environmental affairs [10]. She compared the policy responses in Qatar and Abu Dhabi and found that both had been affected by the dominant global discourse on reducing carbon emissions and experienced serious difficulty transforming their production and consumption patterns. However, while Qatar's energy and environmental policies had largely remained stagnant, Abu Dhabi had seriously begun changing its global position by diversifying its production economy and making friends in international arenas with more progressive partners than just their neighbouring gulf states. It was also investing heavily in Masdar City, at that time known as the world's first zero-carbon city, and an extensive development programme for nuclear energy, both backed by Crown Prince Muhammad al Zayed's powerful Mubadala investment company and undertaken in collaboration with prestigious international partners. Both programmes were aimed at scaling down dependency on traditional energy sources over time, strengthening new innovative high-tech industries and reducing Abu Dhabi's environmental footprint. Although Luomi had not studied Dubai and other emirates, she had reason to believe that efforts to improve the situation there had not even started in earnest. Dubai's reliance on risky financial policies combined with massive land reclamation projects, real estate development and mass entertainment, and Kuwait's lack of policy ambition and initiative due to paralysing struggles between political factions made environmental policy ineffective in these two gulf-states. Later however, in "Building a Sand Castle", Federico Cugurullo (2013) also offered an extremely critical assessment of the business model underlying Masdar City as well as of its actual implementation [41].

If making a transition in production patterns when much of one's economy has been built on oil and gas is a major challenge, realising substantial changes in consumption patterns among local Emiratis and Qataris is at least as problematic. Christopher Davidson (2012) eloquently describes the institutional mechanisms preventing meaningful policy change, even more so than in the rest of the world, as being the consequence of living under a 'rentier state' [15]. Ruling monarchies in the emirates (and other gulf-states such as Saudi Arabia and Oman) have been able to control, accumulate and utilise the national revenue generated through the annual sales of their national oil and gas reserves by establishing massive Sovereign Wealth Funds, but also by distributing financial favours over large segments of the population to keep them satisfied. Inhabitants pay no income taxes; housing, education and healthcare are totally free of charge and energy is available at virtually no charge. These incentives combined with very high incomes and generous conditions for those unable or unwilling to work have led to lifestyles where prosperity and an all-protective state are taken for granted. In this manner, the ruling families and tribes of the respective oil monarchies have been able to acquire popular support and stave off possible resentment and discontent against their leadership [9,15]. However, the downside of these rentier state mechanisms is that many nationals have evolved into complacent citizens and consumers that take this public generosity for granted. Once energy reserves dry up, sales prices abroad go down and the national population rises too fast, the regime will no longer be 
able to provide these services to the same extent and may well rapidly lose credibility. According to Davidson, this menace will eventually phase out these oil monarchies and replace them with more socially and economically inclusive regimes. This process will hit the poorer and less well-endowed emirates, such as Ras al-Khaimah, Umm al-Quwain, Ajman, Fujairah and Sharjah first, then hit Dubai and finally also reach Abu Dhabi and Qatar, which enjoy the largest reserves by far, last. Fromherz (2017), on the other hand, has argued that political scientists often fail to grasp the cultural complexities of Qatari and Emirati societies and purport simplistic analyses [2]. This can obviously be taken as indirectly distancing himself from such far-reaching predictions.

As we know in 2019, no such turnaround in power has taken place in any of these emirates (yet), and this in spite of lower oil and gas prices and a financial crisis from which these states have rebounded (especially Dubai which was hardest hit). Although public discontent has been recorded in the poorer emirates, in the three under study here (Qatar, Abu Dhabi and Dubai), the regimes are still firmly in place and public uproar is virtually absent. In fact, they have even formulated ambitious policy visions, industrial plans and urban master-plans in which they explain how they will engage in ecological modernization through further diversifying and updating their industrial structures, beefing up their education levels, developing into knowledge societies and become leaders in green building and sustainable urban planning. Their well-branded policy documents and project plans seem to suggest that they are well underway to replicate their economic miracle with an environmental one. In the remainder of this contribution, we will examine what holds true of these promises, whether and how the strong brands these emirates represent are indeed perpetuated in recent years and what holds true of Davidson's bold predictions.

\section{Research Design and Methodology}

Although we know that regime change has not happened in any of the emirates and is not immanent in any of them either, this does not immediately invalidate the credibility of the mechanisms on which Davidson's predictions are based. If the theorem of the rentier state in the emirates holds, one can expect that the leadership in Qatar, Abu Dhabi and Dubai will avoid adopting tough policy measures in the sphere of consumption which would negatively affect the comfortable lives their citizens are accustomed to (charges for energy use, subsidies for housing and various other public services, tax levels and prices for imported products). Instead, they would show high levels of ambition when it comes to the transformation of domains where this does not directly hurt citizens and consumers, primarily in the world of industrial and knowledge production, even if such interventions weigh heavily on the public purse. In other words, consumption patterns are unlikely to change much as long as this remains financially feasible, but impressive investments will be made in the promotion of new industries which make a transition possible from the primary and secondary industrial sectors to a more service-oriented economy. This includes the rise of research and education, science and technology, information and communication technology (ICT) infrastructures and renewable energy. Moreover, the focus on the economic growth vehicles that benefit the emirates as a place of consumption for both residents and visitors is boosted through a strong focus on high-quality infrastructure development, real estate development, conspicuous entertainment and tourism. These investments will invariably be labelled 'smart', 'sustainable' and/or 'green' and strong efforts will be made globally to brand these to the world as industrial and urban greening for maintaining a good international reputation. However, the manner in which this responsible attitude towards post oil and global warming is shown to the outside world takes the shape of excellent scores on simple indicators, such as the fastest growth in renewables production in the world and the highest percentage of green buildings in the Middle East. That is, the focus is on catchy but disjointed key performance indicators instead of more holistic figures regarding the ecological footprint, where good performance is hard if not impossible to realise in a desert environment with demanding consumers. 


\subsection{Research Design and Case Selection}

The research design of the present study entails a multi-case study of three emirates. We use a comparative method to analyse key commonalities and differences between these cases in the way they, as rentier states, handle city branding and policy-making regarding sustainable urbanisation. We use a case study research approach because we deem sustainable urban development in the emirates (and cities and regions more generally) a complex phenomenon, which does not lend itself to other research designs such as experiments, surveys or modelling. Moreover, we aim to study the relation between rentier states on the one hand and place branding strategies and policy initiatives on the other in detail, as a current complex phenomenon in its real-life context. We therefore use multiple sources of evidence to gain more reasonable understanding of the situation [42].

Among all emirates only Qatar, Abu Dhabi and Dubai were selected for case study analysis because of what they have achieved in terms of economic growth and global fame. All three have had strong leadership with clear vision and courage to think long term, willingness to undertake risky development projects and aptitude to utilise generous revenues from oil and gas for strengthening their financial position and international profile. In this sense they performed better than other emirates and can be seen as rather 'extreme cases' [43]. We explore and analyse these cases to find evidence on theoretical claims pertaining to rentier states and their drive toward sustainable urbanization.

\subsection{Key Concepts and Operationalization}

In this study the main concepts are threefold: (i) rentier state (as the independent variable), (ii) branding strategies, and (iii) policy initiatives (the last two both as dependent variables). At their turn, both dependent variables are examined in three different realms: those of (1) economic diversification in 'free economic zones', (2) research and higher education in 'education cities' or 'academic cities', and (3) urban expansion in residential areas such as 'sustainable cities'. We decided not to include transport and other infrastructure development, because these are complex to examine and not confined in designated spatial enclaves. Moreover, the different spatial structures of the three emirates with Abu Dhabi having an extremely large size, Qatar in the middle and Dubai being only a fraction of Abu Dhabi and respective urban densities which are approximately the reverse of this, made meaningful comparisons an impossible task. If anything, existing studies indicate that because of its urban structure Dubai's public transport services can be operated reasonably efficiently, while metro and tram facilities in Qatar and Abu Dubai are far harder to operate in cost-effective ways. Table 1 shows how the key concepts in the present study are defined and measured.

Table 1. Definition and measurement of key concepts in the present study.

\begin{tabular}{|c|c|c|}
\hline Key Concept & Definition & Indicator \\
\hline Rentier state & $\begin{array}{l}\text { A state which derives all or a } \\
\text { substantial portion of its national } \\
\text { revenues from the rent of } \\
\text { indigenous resources to external } \\
\text { clients. Dependent upon it as a } \\
\text { source of income, it may generate } \\
\text { rents externally by manipulating } \\
\text { the global political and economic } \\
\text { environment. Such manipulation } \\
\text { may include monopolies, trading } \\
\text { restrictions, and the solicitation of } \\
\text { subsidies or aid in exchange for } \\
\text { political influence [44] }\end{array}$ & $\begin{array}{l}\text { Presence of an autocratic regime with one or a } \\
\text { small number of dominant families able to } \\
\text { control and redistribute the revenues derived } \\
\text { from natural resources. It can use them } \\
\text { intelligently and flexibly to appease its citizens } \\
\text { and (more selectively) immigrant groups to stay } \\
\text { in place. Qatar and Abu Dhabi have high } \\
\text { amounts of natural resources and therefore ample } \\
\text { opportunity to appease, Dubai has limited } \\
\text { amounts of them left. Qatar and Abu Dhabi are } \\
\text { therefore full rentier states, Dubai is a } \\
\text { semi-rentier state. It is now practically a } \\
\text { rentier-service hub, as it is effectively the major } \\
\text { port and business centre for most of the region's } \\
\text { oil and gas rentier states. }\end{array}$ \\
\hline
\end{tabular}


Table 1. Cont.

\begin{tabular}{|c|c|c|}
\hline Key Concept & Definition & Indicator \\
\hline $\begin{array}{l}\text { Place branding } \\
\text { strategy }\end{array}$ & $\begin{array}{l}\text { The practice of conveying a brand } \\
\text { or symbolic essence of a nation, } \\
\text { region or city to target audiences } \\
\text { for enhancing one's fame and } \\
\text { reputation or otherwise obtaining } \\
\text { strategic gain [31] while } \\
\text { acknowledging that geographical } \\
\text { and situational aspects are } \\
\text { sufficiently addressed and setting } \\
\text { the branding strategy and its } \\
\text { objectives is not merely a top } \\
\text { down endeavour, but also } \\
\text { includes involvement of local } \\
\text { stakeholders and citizenry, and a } \\
\text { process be outlined that allows } \\
\text { place elements and place based } \\
\text { associations to combine and form } \\
\text { a place brand }[39,40]\end{array}$ & $\begin{array}{l}\text { Presence of a well-branded policy vision of } \\
\text { economic diversification (1a) } \\
\text { Presence of a well-branded policy vision of } \\
\text { higher education (1b) } \\
\text { Presence of a well-branded policy vision of } \\
\text { sustainable urban expansion (1c) } \\
\text { Presence of a large and conspicuous investment } \\
\text { programme in green-labelled new industries (2a) } \\
\text { Presence of a large and conspicuous investment } \\
\text { programme in higher education ( } 2 \mathrm{~b}) \\
\text { Presence of a large and conspicuous investment } \\
\text { programme in green-labelled residential } \\
\text { expansion projects (2c) }\end{array}$ \\
\hline Policy initiatives & $\begin{array}{l}\text { Specific actions undertaken in } \\
\text { response to generally formulated } \\
\text { policy goals and ambitions and as } \\
\text { such the physical embodiment of } \\
\text { the actual implementation of the } \\
\text { brand }\end{array}$ & $\begin{array}{l}\text { Number and size of spaces displaying the } \\
\text { emergence of non-oil and gas industries ( } 3 a \text { ) } \\
\text { Number and size of spaces displaying the } \\
\text { emergence of a strong research and higher } \\
\text { education system ( } 3 b \text { ) } \\
\text { Number and size of spaces displaying residential } \\
\text { area development with green features (3c) } \\
\text { Emerging variety and characteristics of the } \\
\text { non-oil and gas industries (4a) } \\
\text { Emerging quantity and quality of a thriving } \\
\text { research and higher education system ( } 4 \mathrm{~b}) \\
\text { Emerging green and liveable features in } \\
\text { sustainable residential areas (4c) }\end{array}$ \\
\hline
\end{tabular}

\subsection{Data Collection and Analysis}

In order to collect the relevant data, we have conducted desk research in studying policy documents such as national visions, industrial plans, education plans, urban master plans, infrastructure plans and other relevant publicly available government publications. Online accessibility and completeness of these documents in both English and Arabic was such in Dubai, Abu Dhabi and Qatar that they could be considered reliable information for addressing the branding issues and indicators in Table 1 . Availability of such documents proved problematical in Kuwait, Bahrain, Sharjah, Ras al-Khaimah, Ajman, Umm al-Quwain and Fujairah and little actual activity could be found in these emirates, a good indication of that the fact that the three cases we chose were indeed the appropriate ones for our purposes. In our case, the English versions of these documents were consulted. The availability and contents of these visions, plans and action programmes online and in printed documents allowed us to fill in the information on the branding strategies in the three emirates under study (indicators 1a-c and $2 \mathrm{a}-\mathrm{c}$ ). More detailed desk study and online searches into project documentation, statistics, site visits to several urban development projects (in Abu Dhabi and Dubai) and interviews with thirteen policy makers and experts in the United Arab Emirates and Qatar were used to collect more information on the translation of the brands and vision into actual policy initiatives and actions. Semi-structured questionnaires were used for the interviews pertaining to indicators on the policy initiatives (see Table 1). For all site visits and interviews notes were taken and site reports, and interview transcripts were made. These were analysed and used for filling in the required information on the features and implementation of the investment and development programmes in Table 1 (indicators $3 \mathrm{a}-\mathrm{c}$ and $4 \mathrm{a}-\mathrm{c}$ ). 
Given the strained political relations between the UAE and Qatar, between which direct transport connections have been made impossible, we were unable to visit Qatar. Given the quality of the online documentation available on Qatar, filling out the list of indicators regarding branding practices (indicators $1 \mathrm{a}-\mathrm{c}$ and $2 \mathrm{a}-\mathrm{c}$ ) and policy initiatives (indicators $3 \mathrm{a}-\mathrm{c}$ and $4 \mathrm{a}-\mathrm{c}$ ) were unaffected by this hurdle. To cover the list of indicators on practical policy measures we questioned people in the UAE on the situation in Qatar, on which some of them provided valuable information. Additional interviews were held in Barcelona during a smart city conference and at Delft University of Technology to verify and complement this information.

\section{Visions, Plans, Frameworks and Other Online Sources in Place Branding and Policy-Making}

When it comes to place branding, the three gulf emirates under study here are second to none. All three have reached international fame and their profiles are in many ways similar when it comes to wealth, luxury, entertainment and openness, but vary somewhat in terms of their social and cultural image, with Qatar and Abu Dhabi being more religious and conservative, and Dubai as coming out more profane and liberal. In addition to that Qatar has ventured more into valiant international diplomacy, Abu Dhabi and especially Dubai have remained more aloof from international conflicts under the safe umbrella of the UAE federal government $[2,3,6,18]$. When it comes to the branding of their smart and sustainable urban development, all three emirates have also done a reasonably convincing job, given that on the Sustainability Index issued by large international engineering consultant Arcadis, Dubai ranked first, Abu Dhabi second and Doha (Qatar's capital city) third as sustainable cities in the Middle East region. Still, in the domain of managing their balance between economic growth and environmental preservation, they face a task that is potentially far more challenging than reporting their impressive demographic and economic growth figures.

All three have adopted comprehensive visions or strategies for the future direction of their societies alongside more tactical or sector-specific strategies. The visions carry the respective names of "Qatar National Vision 2030", "Abu Dhabi Policy Agenda 2030", and the "Dubai Plan 2021" [44-46]. All three are directly supported by their respective highest leadership and contain a number of key priority areas or pillars on which government policies should be based.

In the case of Qatar these are: (1) human development (primarily education); (2) social development (justice and preservation of moral standards); (3) economic development (competitive and diversified); and (4) environmental development (harmony between social, economic and environmental aspects).

In Abu Dhabi, the government identified nine pillars constituting the architecture of the Emirate's social, political and economic future: (1) a large empowered private sector; (2) a sustainable knowledge-based economy; (3) an optimal, transparent regulatory environment; (4) a continuation of strong and diverse international relationships; (5) the optimisation of the Emirate's resources; (6) premium education, healthcare and infrastructure assets; (7) complete international and domestic security; (8) maintaining Abu Dhabi's values, culture and heritage; and (9) a significant and ongoing contribution to the federation of the UAE. The Abu Dhabi government has committed itself to direct public policy to strengthen and develop these by focusing on four key priority areas, which are: (1) economic development; (2) social and human resources development; (3) infrastructure development and environmental sustainability; and (4) the optimisation of government operations.

By comparison, the "Dubai Plan 2021" is by far the most explicit and hands-on of the three, by distinguishing six themes: (1) The People: "A City of Happy, Creative \& Empowered People"; (2) The Society: "An Inclusive \& Cohesive Society"; (3) The Experience: "The Preferred Place to Live, Work \& Visit"; (4) The Place: "A Smart \& Sustainable City"; (5) The Economy: "A Pivotal Hub in the Global Economy"; and (6) The Government: "A Pioneering and Excellent Government". In many of these areas, it is explicitly formulated that Dubai aspires to be the world's number one in many or all of these subject areas. As can be seen in Figure 1, all six themes are specified in remarkably sophisticated and optimistic ways and displayed in a special graph. The aspects of smart and sustainable urbanisation are included in various themes, but particularly in 'The Place'. 


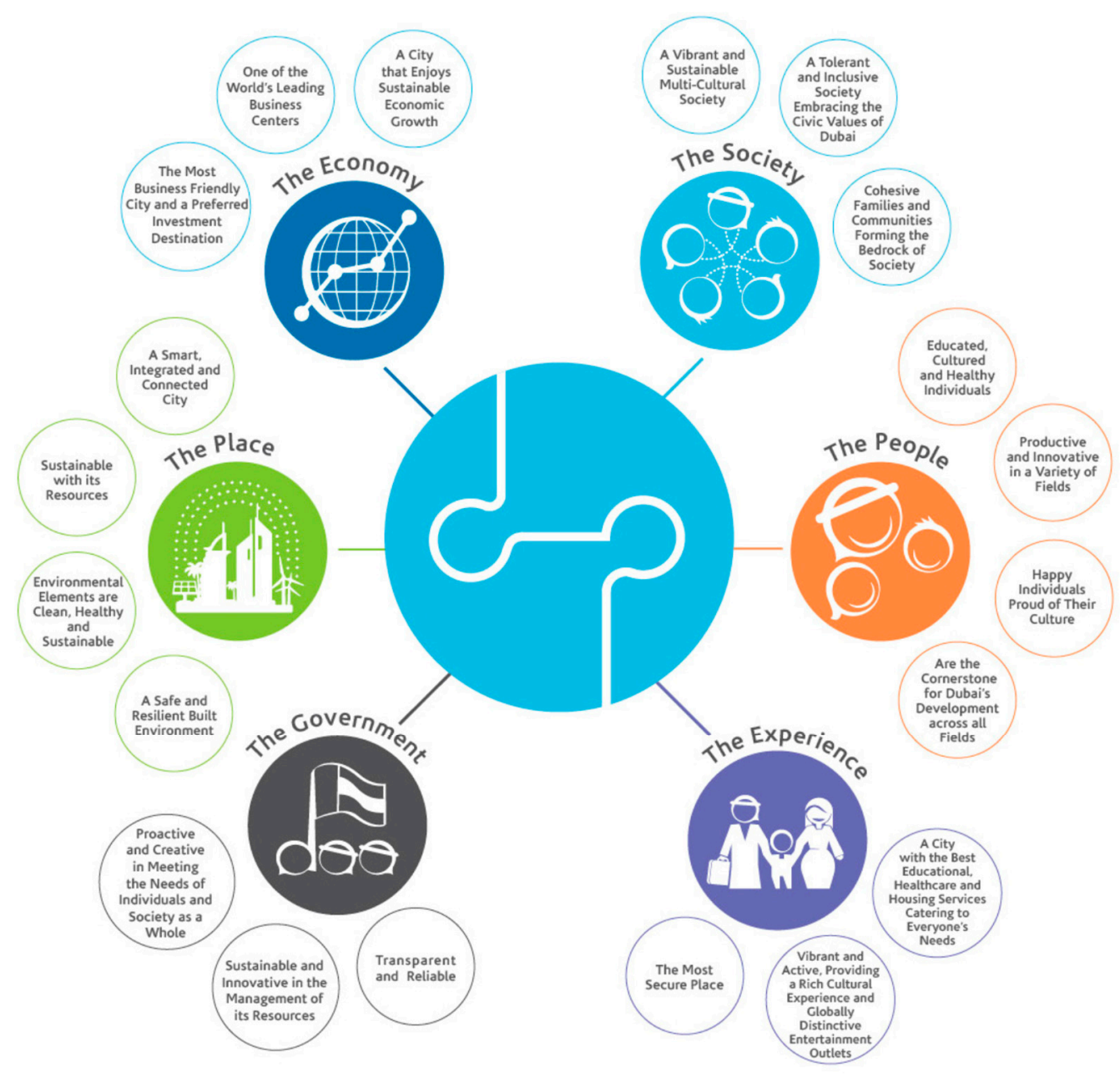

Figure 1. Schematic of the "Dubai Plan 2021".

Hanging below these comprehensive visions, in all three emirates we find more specific or tactical documents which specify these pillars, key areas or themes into investment programmes or actions for different policy areas. In Qatar, we find the 'Qatar National Development Strategy (2011-2016)' and 'Qatar National Development Framework (2032)', the 'Qatar National (urban) Master Plan', and Qatar's '2nd Human Development Report' [47,48]. Abu Dhabi has its 'Plan Abu Dhabi 2030/Urban Structure Framework Plan', 'Abu Dhabi Economic Vision 2030', and 'Abu Dhabi Education Reform: The Road to 2030'. Dubai has issued 'Dubai Industrial Strategy 2030', 'Dubai 2020 Urban Master Plan', and 'Sustainable Dubai 2016'. A cursory glance at all of these publicly available plans and programmes shows that Qatar and Abu Dhabi have relatively elaborate documents, which remain at comparatively strategic and visionary levels of abstraction, while Dubai's selection of government strategies has by far the most concrete, fleshed out, specific and action-oriented tone among the three emirates [48-54].

\section{Branding and Implementing Sustainable Urban Development in Qatar, Abu Dhabi and Dubai}

In their visions, policy plans and investment schemes, Qatar, Abu Dhabi, and Dubai pay ample attention to: (1) the promotion of economic diversification beyond the oil and gas industries alone, (2) the development of a mature innovation system by investing in research and education, and (3) smart and sustainable residential neighbourhood development. In the subsections below (Sections 5.1-5.3), we will address for each of these three types of developed spaces what the vision and plans say about the topic, what the focus of the investment efforts is, and what the number, size and important features of the newly developed sustainable spaces are. 


\subsection{Branding and Implementing Economic Diversification}

In this paper, economic diversification implies the expansion of those economic sectors that go beyond exploiting natural resources alone, both by allowing the state-owned petroleum firms to develop related downstream economic activities, and the promotion of industries and services completely outside of the realm of oil and gas. In their visions and plans, Qatar, Abu Dhabi and Dubai all emphasize the importance of financial services, transport and communication, real estate, tourism and high tech. Nonetheless, the focus in Qatar is more on the promotion of light industry and knowledge exchange in areas where a variety of small and medium-sized enterprises are clustered, while Abu Dhabi tends to emphasize heavy manufacturing and export-oriented industries more. In the case of Dubai, little is said about petroleum related activities in general, which is understandable given the relatively small size of this sector as well as its rapidly declining role therein. All three emirates see the establishment of new, and the expansion of existing industrial and high-tech zones, as major contributors to industrial diversification and long-term global competitiveness. Some of these new industrial and high-tech zones are located in areas where natural resources are extracted (more on downstream processing and manufacturing), while others can be found nearby international ports and airports or elsewhere in town (more for high-tech industries, manufacturing, foreign export and various services). Most of these industrial zones have been designated free economic zones, where special favourable business conditions apply to attract foreign direct investment (FDI). Such conditions pertain to different types of fiscal advantages, such as complete 'tax holidays' up to 50 years, the absence of import duties, permission to establish $100 \%$ foreign owned firms, free repatriation of profits and/or capital, and simplified permitting procedures.

Table 2 shows considerable differences between the three emirates. While the types of favourable conditions granted are roughly the same, it appears that in contrast to Abu Dhabi and Qatar, Dubai began the practice of establishing free economic zones many years ago and now has many of them across its territory: 21 by the 1st of January 2019, to be exact. Within the UAE, Dubai stands apart as it has developed a reputation for international commerce long before its first free trade zone which was established in the 1980s [55]. Most are rather small in size but go by attractive names such as "Dubai Silicon Oasis", "Dubai Internet City", "Dubai Design District", “Gold and Diamond Park", and "Dubai Media City". Dubai uses sophisticated branding slogans. Abu Dhabi, on the other hand, merely enjoys the presence of four free economic zones, while Qatar only has one. As can be seen, these were established far later than those in Dubai. Nonetheless, they count far more square kilometres of developed economic zone area and can therefore contain a larger number of corporations. Qatar, in fact, only began this practice quite recently in response to the economic boycott of its Arab neighbours and has aimed to establish various spaces within its large "Education City" as free economic zones. In all three emirates though, the goal is to foster the emergence and evolution of technological clusters, such as in biotechnology, aerospace engineering, green technologies and services, ICT, health, and education. Apart from the Economic Free Zones mentioned above, all three emirates have developed a number of industrial zones and cities for their domestic manufacturing industries, which do not enjoy these special business conditions. 
Table 2. Free economic zones and their main features in Qatar, Abu Dhabi and Dubai.

\begin{tabular}{|c|c|c|c|c|c|c|}
\hline Emirates & Name & $\begin{array}{l}\text { The Year of } \\
\text { Establishment }\end{array}$ & Profile/Brand & Area/Location & Investment/Source of Funding & Type of Industries/Institutions Are in \\
\hline \multirow{17}{*}{ Dubai } & Jebel Ali Free Zone & 1985 & $\begin{array}{l}\text { A unique trade ecosystem that } \\
\text { reduces cost, while enabling new } \\
\text { opportunities for growth. }\end{array}$ & $\begin{array}{l}57 \mathrm{sq} . \mathrm{km} / \mathrm{Jebel} \text { Ali area at the far } \\
\text { western end of Dubai }\end{array}$ & governmental funding & $\begin{array}{l}\text { Logistics, Warehousing, Economic Trade } \\
\text { Zone, Real Estate, Property }\end{array}$ \\
\hline & Dubai Airport Free Zone & 1996 & $\begin{array}{l}\text { The fastest growing Zone in the } \\
\text { world }\end{array}$ & $\begin{array}{l}11 \text { sq.km/Next to Dubai } \\
\text { International Airport }\end{array}$ & governmental funding & $\begin{array}{l}\text { Light manufacturing activities, Trading } \\
\text { \& General Trading, Services }\end{array}$ \\
\hline & Dubai Internet City & 1999 & Innovation begins here & $\begin{array}{l}139 \text { sq. m/adjacent to Dubai } \\
\text { Marina, Jumeirah Beach } \\
\text { Residence }\end{array}$ & $\begin{array}{l}\text { Dubai Holding subsidiary } \\
\text { TECOM * Investments }\end{array}$ & $\begin{array}{l}\text { Information and communications } \\
\text { technology (ICT) companies }\end{array}$ \\
\hline & $\begin{array}{l}\text { Dubai Car \& Automotive City } \\
\text { Free Zone }\end{array}$ & 2000 & $\mathrm{n} / \mathrm{a}$ & 743 sq. m/Ras Al Khor & & Automotive industry \\
\hline & Dubai Media City & 2001 & The region's leading media hub & Next to the Palm Jumeirah & TECOM Group & Media industry and services \\
\hline & $\begin{array}{l}\text { Dubai Multi Commodities } \\
\text { Center }\end{array}$ & 2002 & The world's \#1 free zone & $\begin{array}{l}2 \text { sq.km/located in Jumeirah } \\
\text { Lakes }\end{array}$ & DMCC is a government entity & Trading, Service, Industrial \\
\hline & Dubai Healthcare City & 2002 & Your Health \& Wellness Destination & 2.5 sq. km/Sheikh Zayed Road & governmental funding & Healthcare and clinical industry \\
\hline & Dubai Techno Park & 2002 & n/a & 21.3 sq. km/Jebel Ali & governmental funding & $\begin{array}{l}\text { High-profile companies specializing in } \\
\text { technology, oil, gas and petrochemical } \\
\text { industry and other industries }\end{array}$ \\
\hline & Intl Media Production Zone & 2003 & n/a & $\begin{array}{l}4 \mathrm{sq} . \mathrm{km} / \text { Dubai International } \\
\text { Financial Centre }\end{array}$ & TECOM Group & Media production Industry \\
\hline & Dubai Silicon Oasis & 2004 & $\begin{array}{l}\text { The integrated free zone technology } \\
\text { park }\end{array}$ & $\begin{array}{l}97740 \text { sq. } \mathrm{m} / \text { Middle of Dubai } \\
\text { land }\end{array}$ & governmental funding & $\begin{array}{l}\text { Services, Trading, Industrial: import raw } \\
\text { material, manufacture, and process, } \\
\text { assemble, package and export the } \\
\text { finished product. }\end{array}$ \\
\hline & Dubai Industrial City & 2004 & $\begin{array}{l}\text { The leading manufacturing and } \\
\text { logistics hub }\end{array}$ & $\begin{array}{l}52 \mathrm{sq} . \mathrm{km} / \mathrm{Next} \text { to Jebel Ali } \\
\text { International Airport }\end{array}$ & TECOM Group & Light and medium manufacturing \\
\hline & Dubai Intl Financial Centre & 2004 & Gateway to Growth & 0.5 sq. km/Sheikh Zayed Road & governmental funding & $\begin{array}{l}\text { Finance, Banking \& Brokerage Services, } \\
\text { Wealth Management, Reinsurance \& } \\
\text { Captive Insurance, }\end{array}$ \\
\hline & Dubai Studio City & 2005 & Unleash your imagination & $\begin{array}{l}2 \text { sq. km/Sheikh Mohammad bin } \\
\text { Zayed Road }\end{array}$ & TECOM Group & Film and broadcasting industry \\
\hline & Dubai South & 2006 & $\begin{array}{l}\text { The City of You-is an emerging } \\
\text { master-planned city based on } \\
\text { happiness of the individual. }\end{array}$ & $\begin{array}{l}145 \mathrm{sq} . \mathrm{km} / \text { around Al Maktoum } \\
\text { International Airport }\end{array}$ & $\begin{array}{l}\text { governmental and private } \\
\text { funding }\end{array}$ & $\begin{array}{l}\text { Light manufacturing activities, Logistics, } \\
\text { Trading \& General Trading, Educational } \\
\text { and training, and educational } \\
\text { consultancy services. }\end{array}$ \\
\hline & Dubai Outsource Zone & 2007 & $\begin{array}{l}\text { An outstanding business park } \\
\text { dedicated to local and international } \\
\text { outsourcing companies }\end{array}$ & Emirates Road & TECOM Group & $\begin{array}{l}\text { Services: Business Process Outsourcing } \\
\text { (BPO), HR Outsourcing, IT Outsourcing, } \\
\text { back office and call center operations }\end{array}$ \\
\hline & Gold and Diamond Park & 2011 & $\begin{array}{l}\text { The Finest Creations, All Under One } \\
\text { Roof }\end{array}$ & 47.5 sq. m/Sheikh Zayed Road & EMAAR group & $\begin{array}{l}\text { Jewellery (gemstones, precious stones, } \\
\text { gold, silver, platinum) trading, } \\
\text { manufacturing, retails and services }\end{array}$ \\
\hline & Dubai Design District(D3) & 2013 & $\begin{array}{l}\text { A home for the region's creative } \\
\text { thinkers }\end{array}$ & $\begin{array}{l}130 \text { sq. } \mathrm{m} / \text { Next to Business Bay, } \\
\text { Dubai Mall, and Burj Khalifa }\end{array}$ & governmental funding & Digital media, arts, design, and fashion \\
\hline
\end{tabular}


Table 2. Cont.

\begin{tabular}{|c|c|c|c|c|c|c|}
\hline Emirates & Name & $\begin{array}{l}\text { The Year of } \\
\text { Establishment }\end{array}$ & Profile/Brand & Area/Location & Investment/Source of Funding & Type of Industries/Institutions Are in \\
\hline \multirow{8}{*}{ Abu Dhabi } & Khalifa Industrial Zone (KIZAD) & 2010 & $\begin{array}{l}\text { The Integrated Trade, Logistics and } \\
\text { Industrial Hub of Abu Dhabi }\end{array}$ & $\begin{array}{l}410 \text { sq. } \mathrm{km} / \mathrm{located} \text { almost } \\
\text { equidistant between Abu Dhabi } \\
\text { and Dubai }\end{array}$ & governmental funding & $\begin{array}{l}\text { Trade \& logistics, Manufacturing; } \\
\text { aluminum, food \& beverage, } \\
\text { pharmaceutical Packaging }\end{array}$ \\
\hline & $\begin{array}{l}\text { Higher Corporation for } \\
\text { Specialized Economic Zones }\end{array}$ & 2004 & A hub for a number of training & $\begin{array}{l}14 \text { sq. km/close to Musafah Sea } \\
\text { Port, Abu Dhabi International } \\
\text { Airport }\end{array}$ & governmental funding & $\begin{array}{l}\text { Heavy to medium manufacturing, } \\
\text { processing, and engineering activities }\end{array}$ \\
\hline & Masdar City Free Zone & 2006 & $\begin{array}{l}\text { An emerging global hub for clean } \\
\text { technologies and renewable energy }\end{array}$ & $\begin{array}{l}6 \mathrm{sq} \cdot \mathrm{km} / 6 \text { kilometers away from } \\
\text { the Abu Dhabi }\end{array}$ & $\begin{array}{l}\text { Mubadala Development } \\
\text { Company }\end{array}$ & Future green technology products \\
\hline & Twofour54 & 2008 & $\begin{array}{l}\text { One of the fastest growing media } \\
\text { free zones in the region. }\end{array}$ & $\begin{array}{l}\text { Proximity to Downtown Abu } \\
\text { Dhabi }\end{array}$ & $\mathrm{n} / \mathrm{a}$ & Media businesses \\
\hline & $\begin{array}{l}\text { Industrial City of Abu Dhabi } \\
\text { (ICAD) }\end{array}$ & 2008 & $\mathrm{n} / \mathrm{a}$ & $\begin{array}{l}40 \text { sq. m/located in the outskirts } \\
\text { of Abu Dhabi city }\end{array}$ & $\mathrm{n} / \mathrm{a}$ & $\begin{array}{l}\text { Heavy-to-medium \& Light-to-medium } \\
\text { manufacturing, engineering and } \\
\text { processing industries. }\end{array}$ \\
\hline & Abu Dhabi Airport Free Zone & 2010 & $\begin{array}{l}\text { A new global business address at the } \\
\text { heart of Abu Dhabi Airports } \\
\text { operations, will accelerate Abu } \\
\text { Dhabi's economic diversification }\end{array}$ & $\begin{array}{l}12 \text { sq. km/near Abu Dhabi } \\
\text { International Airport }\end{array}$ & $\begin{array}{l}\text { governmental funding/owned } \\
\text { subsidiary of Abu Dhabi } \\
\text { Airports }\end{array}$ & $\begin{array}{l}\text { Aerospace and Aviation industry, } \\
\text { Airport \&, Airline Services, Marketing } \\
\text { and Events, Knowledge and } \\
\text { Development }\end{array}$ \\
\hline & $\begin{array}{l}\text { Abu Dhabi Ports Company } \\
\text { (ADPC) Free Zone }\end{array}$ & 2012 & $\begin{array}{l}\text { Abu Dhabi Port Company (ADPC) is } \\
\text { a good spot for industries and } \\
\text { trading companies. }\end{array}$ & $\begin{array}{l}2.7 \mathrm{sq} . \mathrm{km} / \mathrm{between} \text { Dubai and } \\
\text { Abu Dhabi, in Taweelah }\end{array}$ & governmental funding & $\begin{array}{l}\text { Trade, industrial production of goods, } \\
\text { services like banking, management } \\
\text { consultancy or other professional } \\
\text { services }\end{array}$ \\
\hline & $\begin{array}{l}\text { Abu Dhabi Global Market Free } \\
\text { Zone }\end{array}$ & 2013 & $\begin{array}{l}\text { An ideal location for investors to set } \\
\text { up a company in the financial sector. }\end{array}$ & 1.14 sq. km/Al Maryah Island & $\begin{array}{l}\text { governmental funding in } \\
\text { collaborating with the bigwigs } \\
\text { (International funding) }\end{array}$ & Financial service industry \\
\hline \multirow{2}{*}{ Qatar } & $\begin{array}{l}\text { Airport Free Zone—RAS } \\
\text { BUFONTAS }\end{array}$ & 2018 & $\begin{array}{l}\text { Technology, Trading and Logistics } \\
\text { Hub }\end{array}$ & $\begin{array}{l}3.96 \text { sq. km/Adjacent to Hamad } \\
\text { International Airport (HIA) }\end{array}$ & $\begin{array}{l}\text { governmental funding/Qatar } \\
\text { Free Zones Authority }\end{array}$ & $\begin{array}{l}\text { Light Manufacturing, International } \\
\text { Business Services, Aviation Sector, } \\
\text { Emerging Technologies Logistics Hub }\end{array}$ \\
\hline & Port Free Zone-UM ALHOUL & 2018 & Hub with Industrial Focus & $\begin{array}{l}30.3 \text { sq. km/Adjacent to the } \\
\text { Mesaieed Industrial Zone \& } \\
\text { Hamad Port }\end{array}$ & $\begin{array}{l}\text { governmental funding/Qatar } \\
\text { Free Zones Authority }\end{array}$ & $\begin{array}{l}\text { Maritime Industries, Heavy } \\
\text { Manufacturing, Industrial Sectors Focus, } \\
\text { Emerging Technologies, Logistics Hub }\end{array}$ \\
\hline
\end{tabular}


To what extent have these policies indeed led to industrial diversification? Table 3 shows that Dubai now leans for over $90 \%$ of its GDP on economic activities unrelated to oil and gas, whereas Abu Dhabi and Qatar for which the industry breakdown is remarkably similar - still continue to lean on their natural oil and gas resources for roughly one-third of their GDP generation, with mining and quarrying still high on the list. If the aim is to move to more ecological modernisation, having these resource intensive and polluting industries in place might not be a good sign.

Table 3. Industrial diversification in Qatar, Abu Dhabi and Dubai.

\begin{tabular}{|c|c|c|c|c|c|}
\hline \multicolumn{2}{|l|}{ Dubai } & \multicolumn{2}{|l|}{ Abu Dhabi } & \multicolumn{2}{|l|}{ Qatar } \\
\hline Economic Activity & $\begin{array}{l}\text { GDP Share } \\
\%(2017)\end{array}$ & Economic Activity & $\begin{array}{l}\text { GDP Share } \\
\%(2016)\end{array}$ & Economic Activity & $\begin{array}{l}\text { GDP Share } \\
\%(2016)\end{array}$ \\
\hline $\begin{array}{l}\text { Wholesale and retail trade; } \\
\text { repair of motor vehicles and } \\
\text { motorcycles }\end{array}$ & 25.8 & $\begin{array}{l}\text { Mining and quarrying } \\
\text { (including crude oil } \\
\text { and natural gas) }\end{array}$ & 35.9 & Mining and quarrying & 30.3 \\
\hline Transportation and storage & 11.2 & Construction & 9.9 & Construction & 11.9 \\
\hline $\begin{array}{c}\text { Financial and insurance } \\
\text { activities }\end{array}$ & 11 & $\begin{array}{c}\text { Financial and } \\
\text { insurance activities }\end{array}$ & 9.0 & $\begin{array}{l}\text { Wholesale and retail trade; } \\
\text { repair of motor vehicles and } \\
\text { motorcycles }\end{array}$ & 10.0 \\
\hline Manufacturing & 9 & $\begin{array}{l}\text { Public administration } \\
\text { and defence; } \\
\text { compulsory social } \\
\text { security }\end{array}$ & 7.3 & $\begin{array}{c}\text { Financial and insurance } \\
\text { activities }\end{array}$ & 9.6 \\
\hline Real estate activities & 6.8 & Manufacturing & 6.5 & Manufacturing & 9.0 \\
\hline $\begin{array}{l}\text { Public administration and } \\
\text { defense; compulsory social } \\
\text { security }\end{array}$ & 6.8 & $\begin{array}{l}\text { Wholesale and retail } \\
\text { trade; repair of motor } \\
\text { vehicles and } \\
\text { motorcycles }\end{array}$ & 5.7 & $\begin{array}{l}\text { Public administration and } \\
\text { defense; compulsory social } \\
\text { security }\end{array}$ & 8.7 \\
\hline Construction & 6.5 & Real estate activities & 5.4 & Real estate activities & 7.7 \\
\hline $\begin{array}{l}\text { Professional, scientific and } \\
\text { technical activities }\end{array}$ & 4 & $\begin{array}{c}\text { Electricity, gas, and } \\
\text { water supply; waste } \\
\text { management activities }\end{array}$ & 4.1 & $\begin{array}{l}\text { Financial intermediation } \\
\text { services indirectly measured } \\
\text { (FISIM) }\end{array}$ & 4.7 \\
\hline $\begin{array}{l}\text { Information and } \\
\text { communication }\end{array}$ & 4 & $\begin{array}{l}\text { Transportation and } \\
\text { storage }\end{array}$ & 3.3 & $\begin{array}{c}\text { Professional, scientific and } \\
\text { technical activities; } \\
\text { Administrative and support } \\
\text { service activities }\end{array}$ & 3.7 \\
\hline $\begin{array}{l}\text { Accommodation and food } \\
\text { service activities }\end{array}$ & 4 & $\begin{array}{l}\text { Information and } \\
\text { communication }\end{array}$ & 2.8 & Transportation and storage & 3.3 \\
\hline $\begin{array}{l}\text { Electricity, gas, steam and air } \\
\text { conditioning supply }\end{array}$ & 3.4 & $\begin{array}{l}\text { Professional, scientific } \\
\text { and technical activities }\end{array}$ & 2.4 & Education & 2.1 \\
\hline $\begin{array}{l}\text { Administrative and support } \\
\text { service activities }\end{array}$ & 3.3 & $\begin{array}{l}\text { Administrative and } \\
\text { support service } \\
\text { activities }\end{array}$ & 1.6 & $\begin{array}{l}\text { Human health and social } \\
\text { work activities }\end{array}$ & 2.0 \\
\hline Mining and quarrying & 1 & Education & 1.6 & $\begin{array}{l}\text { Information and } \\
\text { communication }\end{array}$ & 1.8 \\
\hline $\begin{array}{c}\text { Human health and social } \\
\text { work activities }\end{array}$ & 1 & $\begin{array}{l}\text { Human health and } \\
\text { social work activities }\end{array}$ & 1.6 & $\begin{array}{l}\text { Arts, entertainment and } \\
\text { recreation; other service } \\
\text { activities }\end{array}$ & 1.6 \\
\hline Education & 0.7 & $\begin{array}{l}\text { Accommodation and } \\
\text { food service activities }\end{array}$ & 1.2 & $\begin{array}{l}\text { Accommodation and food } \\
\text { service activities }\end{array}$ & 1.2 \\
\hline Other service activities & 0.5 & $\begin{array}{l}\text { Agriculture, forestry } \\
\text { and fishing }\end{array}$ & 0.7 & $\begin{array}{c}\text { Electricity, gas, water supply, } \\
\text { sewerage and waste } \\
\text { management }\end{array}$ & 0.7 \\
\hline $\begin{array}{l}\text { Activities of households as } \\
\text { employers; undifferentiated } \\
\text { goods- and } \\
\text { services-producing activities } \\
\text { of households for own use }\end{array}$ & 0.5 & $\begin{array}{l}\text { Activities of } \\
\text { households as } \\
\text { employers }\end{array}$ & 0.6 & $\begin{array}{l}\text { Activities of households as } \\
\text { employers; undifferentiated } \\
\text { goods and services producing } \\
\text { activities of households for } \\
\text { own use }\end{array}$ & 0.7 \\
\hline $\begin{array}{l}\text { Arts, entertainment and } \\
\text { recreation }\end{array}$ & 0.3 & \multirow{3}{*}{$\begin{array}{l}\text { Arts, recreation and } \\
\text { other service activities }\end{array}$} & \multirow{3}{*}{0.3} & Import duties & 0.3 \\
\hline $\begin{array}{c}\text { Water supply; sewerage, } \\
\text { waste management and } \\
\text { remediation activities }\end{array}$ & 0.1 & & & \multirow[t]{2}{*}{$\begin{array}{c}\text { Agriculture, forestry and } \\
\text { fishing }\end{array}$} & \multirow[t]{2}{*}{0.2} \\
\hline $\begin{array}{l}\text { Agriculture, forestry and } \\
\text { fishing }\end{array}$ & 0.1 & & & & \\
\hline Gross Domestic Product & 100 & 100 & & 100 & \\
\hline
\end{tabular}




\subsection{Branding and Implementing the Development of an Innovation System}

The Qatar, Abu Dhabi and Dubai governments all consider high-level research a key asset to their long-term technological development and find a highly educated population with the skills required for a thriving economy in the 21st century vital to mobilise the rising numbers of local youth. Among the three emirates, Qatar is the most outspoken on this matter and even made human development one of its four key priority areas. Both Qatar and Abu Dhabi explicitly mention the relevance of social, moral and religious values in the education system, while tolerance and cosmopolitan attitudes come more to the fore in the case of Dubai's policy documents. In a similar vein as for economic diversification, special designated areas are sought that can function as receptacles for efforts to strengthen the national higher education system. The most famous one is 'Education City' in Qatar, in which elite international academic institutes were invited and on which \$ US 2 billion was spent through the 'Qatar Foundation' (United Nations Global Compact, 2015). Established within this internationally oriented 'Education City' are campuses of Virginia Commonwealth University, Weill Cornell Medical College, Texas A\&M University, Carnegie Mellon University, Georgetown University School of Foreign Service, Northwestern University and HEC Paris. Another large research and education programme, and one with a more national orientation, is 'Qatar Science and Technology Park', which received monetary resources from the Qatar National Research Fund. Qatar University, the main domestic university, is located there and still boasts higher student numbers than its international counterparts. In sum, Qatar is reported to spend around 9.3\% of its total expenditure on education, which is clearly the highest in the Middle East/North Africa region [47]. Abu Dhabi has also found a sizeable number of international universities willing to set up subsidiaries within its borders, i.e., University of Strathclyde Business School, New York University, European International College, New York Institute of Technology, Paris Sorbonne University and Université Mohammed V-Agdal Abu Dhabi. The Abu Dhabi government targets its research funding mainly at the sectors microelectronics, health, culture and heritage and various forms of energy. The lion's share of its funds for research and educational development is earmarked to the Masdar Institute of Science and Technology (MIST), funded by Abu Dhabi's financial powerhouse, the Mubadala Investment Corporation. MIST is located within Masdar City, which historically was branded the first zero carbon town in the world. MIST, in which Massachusetts Institute of Technology plays an active role, targets the education and training of the future energy leaders in new specialized fields, it pushes R\&D for technological innovation in sustainability, and supports the development of a knowledge-based economy [51]. Recent evidence (www.masdar.ac.ae) and insights gained from our own fieldwork (site visit and interviews) suggest that its expansion has stalled in recent years, and that it no longer exists as an independent institute and has been integrated with Khalifa University and become a part of the regular Abu Dhabi higher education system. In addition to MIST, Abu Dhabi also has a number of domestic universities (Abu Dhabi University, Khalifa University, Al Ain University of Science and Technology) and the federal Zayed University, which has campuses in both Abu Dhabi and in Dubai. Dubai's main higher education project is Dubai International Academic City, which has collected the highest number of international higher education institutes. However, as Table 4 shows, these academic institutes can all be found together in an area more or less the same size as Qatar's Education City while the funds in Dubai are mostly derived from private sector investments. Dubai's International Academic City lists academic institutes with lower positions on international rankings and is therefore far less significant as an attempt to grow a world-class high-tech innovation system than Qatar and Abu Dhabi. 
Table 4. Academic institutions in Qatar, Abu Dhabi and Dubai.

\begin{tabular}{|c|c|c|c|c|c|}
\hline Emirates & Location & University & Level of Study & $\begin{array}{l}\text { Established } \\
\text { in Dubai }\end{array}$ & $\begin{array}{l}\text { Number of } \\
\text { Students }\end{array}$ \\
\hline \multirow{36}{*}{ Dubai } & \multirow{19}{*}{$\begin{array}{l}\text { Dubai International } \\
\text { Academic City }\end{array}$} & University of Dubai & Bachelor, Master, PhD & 1997 & 768 \\
\hline & & Zayed university* & Bachelor, Master & 1998 & 2114 \\
\hline & & Higher Colleges of Technology* & Applied Diploma, Bachelor, Master & 1988 & 733 \\
\hline & & $\begin{array}{l}\text { The National Institute for Vocational } \\
\text { Education }\end{array}$ & Diploma, Certificate & 2006 & 210 \\
\hline & & Amity University Dubai & Bachelor, Master, $\mathrm{PhD}$ & 2011 & 1882 \\
\hline & & $\begin{array}{c}\text { Birla Institute of Technology and Science } \\
\text { Pilani }\end{array}$ & Bachelor, Master, PhD & 2000 & 1603 \\
\hline & & British University in Dubai & Bachelor, Master, $\mathrm{PhD}$ & 2004 & 1139 \\
\hline & & Cambridge College International & $\mathrm{n} / \mathrm{a}$ & 2007 & 69 \\
\hline & & Curtin University & $\begin{array}{l}\text { Undergraduate, Postgraduate } \\
\text { coursework }\end{array}$ & 2017 & 10 \\
\hline & & ESMOD French Fashion Institute & Bachelor, Certificate & 2006 & 103 \\
\hline & & Heriot-Watt University & Bachelor, Master, $\mathrm{PhD}$ & 2005 & 3644 \\
\hline & & Institute of Management Technology Dubai & Bachelor, Master & 2006 & 499 \\
\hline & & MENA College of Management & Bachelor & 2014 & 292 \\
\hline & & Manipal Academy of Higher Education & Bachelor, Master, PhD & 2003 & 2343 \\
\hline & & Murdoch University & Diploma, Bachelor, Master & 2008 & 718 \\
\hline & & S P Jain School of Global Management & Bachelor, Master, $\mathrm{PhD}$ & 2004 & 1628 \\
\hline & & $\begin{array}{l}\text { Shaheed Zulfikar Ali Bhutto Institute of } \\
\text { Science and Technology }\end{array}$ & Bachelor & 2003 & 706 \\
\hline & & University of Birmingham & Bachelor, Master & $\mathrm{n} / \mathrm{a}$ & $\mathrm{n} / \mathrm{a}$ \\
\hline & & University of St. Joseph & Bachelor & 2008 & 69 \\
\hline & \multirow{8}{*}{$\begin{array}{c}\text { Dubai Knowledge } \\
\text { Village }\end{array}$} & Islamic Azad University & Bachelor, Master, $\mathrm{PhD}$ & 2004 & 423 \\
\hline & & Michigan State University & Master & 2008 & $\mathrm{n} / \mathrm{a}$ \\
\hline & & Middlesex University & Bachelor, Master & 2005 & 3141 \\
\hline & & SAE Institute & Bachelor & 2005 & 403 \\
\hline & & The University of Manchester & Master & 2005 & 529 \\
\hline & & University of Bradford & Master & 2009 & 132 \\
\hline & & University of Exeter & Bachelor, Master, PhD & 2006 & 49 \\
\hline & & University of Wollongong & Bachelor, Master, $\mathrm{PhD}$ & 1993 & 3905 \\
\hline & \multirow{2}{*}{ Dubai Internet City } & Emirates Aviation University & $\begin{array}{l}\text { Diploma, Certificate, Bachelor, } \\
\text { Master }\end{array}$ & 1991 & 1537 \\
\hline & & Hult International Business School & Bachelor, Master & 2008 & 395 \\
\hline & Dubai Media City & American University & $\begin{array}{l}\text { Diploma, Certificate, Bachelor, } \\
\text { Master }\end{array}$ & 1995 & 2297 \\
\hline & Dubai Silicon Oasis & Rochester Institute of Technology & Bachelor, Master & 2008 & 891 \\
\hline & Dubai South & University of South Wales & Bachelor, Master & 2017 & $\mathrm{n} / \mathrm{a}$ \\
\hline & \multirow{2}{*}{$\begin{array}{l}\text { Jumeirah Lake } \\
\text { Towers }\end{array}$} & $\begin{array}{l}\text { Moscow University for Industry and } \\
\text { Finance }\end{array}$ & Bachelor, Master & 2013 & 95 \\
\hline & & MODUL University & Bachelor, Master & 2016 & 255 \\
\hline & Deira & London Business School & Master & 2006 & 208 \\
\hline & $\begin{array}{l}\text { Dubai International } \\
\text { Financial Centre }\end{array}$ & CITY University of London & Bachelor, Master & 2007 & 240 \\
\hline \multirow{14}{*}{ Abu Dhabi } & \multirow{9}{*}{ City of Abu Dhabi } & Khalifa University * & Bachelor, Master, PhD & 1989 & 1336 \\
\hline & & Petroleum Institute & $\mathrm{n} / \mathrm{a}$ & 2006 & 1654 \\
\hline & & Abu Dhabi Polytechnic & Diploma, Certificate, Bachelor & 2010 & 642 \\
\hline & & Emirates College for Advanced Education & Bachelor, Master, PhD & 1993 & 369 \\
\hline & & University of Strathclyde & Bachelor, Master & 1995 & 201 \\
\hline & & New York Institute of Technology & Bachelor, Master & 2005 & 163 \\
\hline & & Sorbonne University & Bachelor, Master & 2006 & 630 \\
\hline & & Mohammed V University & Bachelor, Master, $\mathrm{PhD}$ & 2009 & $\mathrm{n} / \mathrm{a}$ \\
\hline & & Abu Dhabi School of Management & Master & 2013 & 250 \\
\hline & Khalifa city & Abu Dhabi University & Bachelor, Master, $\mathrm{PhD}$ & 2003 & 4374 \\
\hline & Masdar City & Masdar Institute & $\mathrm{n} / \mathrm{a}$ & 2007 & 417 \\
\hline & Al Mafraq hospital & Fatma College of Health Sciences & Bachelor & 2006 & 612 \\
\hline & $\begin{array}{l}\text { Mohammed Bin } \\
\text { Zayed City }\end{array}$ & $\begin{array}{l}\text { Abu Dhabi Vocational Education and } \\
\text { Training Institute }\end{array}$ & Diploma, Certificate & 2007 & 766 \\
\hline & Saadiyat Island & New York University & Bachelor & 2010 & 618 \\
\hline
\end{tabular}


Table 4. Cont.

\begin{tabular}{|c|c|c|c|c|c|}
\hline Emirates & Location & University & Level of Study & $\begin{array}{l}\text { Established } \\
\text { in Dubai }\end{array}$ & $\begin{array}{l}\text { Number of } \\
\text { Students }\end{array}$ \\
\hline \multirow{14}{*}{ Qatar } & \multirow{4}{*}{ City of Doha } & Qatar University * & Bachelor, Master, PhD & 1973 & 14000 \\
\hline & & American Education Center & Certificate & 2005 & 400 \\
\hline & & Doha Institute for Graduate studies * & Master & 2011 & 350 \\
\hline & & College of North Atlantic & Diploma, Bachelor & 2002 & 2000 \\
\hline & \multirow{9}{*}{ Education City-Doha } & Hamad Bin Khalifa University * & Master, $\mathrm{PhD}$ & 2010 & 6000 \\
\hline & & Carnegie Mellon University & Bachelor & 2004 & 384 \\
\hline & & Weill Cornell Medical College & Bachelor & 2001 & $\mathrm{n} / \mathrm{a}$ \\
\hline & & Northwestern University & Bachelor & 2008 & $\mathrm{n} / \mathrm{a}$ \\
\hline & & HEC Paris & Master, Certificate & 2010 & 4000 \\
\hline & & Academic Bridge & Diploma, Certificate & 2001 & $\mathrm{n} / \mathrm{a}$ \\
\hline & & $\begin{array}{l}\text { Georgetown university school of foreign } \\
\text { service }\end{array}$ & Bachelor & 2005 & $\mathrm{n} / \mathrm{a}$ \\
\hline & & Texas A\&M University & Bachelor, Master & 2003 & 635 \\
\hline & & Virginia Commonwealth University & Bachelor, Master & 2010 & 339 \\
\hline & Cultural Village & Doha Film Institute & Certificate & 2010 & $\mathrm{n} / \mathrm{a}$ \\
\hline
\end{tabular}

While the number of domestic and especially international universities in the three emirates is impressive, especially in view of their population size, it is less clear how comprehensive the range of the Bachelor, Master and $\mathrm{PhD}$ degrees is that these universities and research institutes offer and to what extent the campuses where they are located can be seen as promising building blocks for a thriving high-tech innovation system.

\subsection{Branding and Implementing the Smart and Sustainable Cities}

In light of rising population numbers and increased wealth, it goes without saying that all three emirates have experienced and are still experiencing rapid urban expansion. The question is to what extent smart and sustainable features highlighted in their plans are reflected in new urban development projects. In 2010, Abu Dhabi was the first among them to launch a green building code called 'Estidama'. It consists of environmental, economic, social and cultural aspects, and makes a distinction in five different types of buildings (office, retail, multi-residential, school and mixed uses). It awards 'Pearl credit points' for sustainable solutions (with a minimum score of 1 being legally compulsory) and is to be applied to all new buildings in Abu Dhabi. Qatar also adopted green building standards, entitled the 'Qatar Sustainability Assessment System' (later renamed to 'Global Sustainability Assessment System') which applies urban connectivity, site, energy, water, materials, indoor environment, cultural and economic values and management and operations as relevant themes. Government buildings have been required to adopt this assessment framework from 2016 on, but the enlargement of its wider application is yet to be realized [56]. Dubai currently has the most demanding regulatory system for green buildings in place: it has adopted compulsory green building regulations which apply to all types of building construction. These are to be used regardless of other rating systems and are not intended merely to substitute these. Here, distinction is made between villas, commercial buildings, public buildings and industrial buildings, and for each of these categories' application can occur to new constructions, additions/extensions/refurbishments and existing buildings. One could say that while Abu Dhabi came first among the three emirates, Dubai is now seen as the frontrunner in promoting green buildings. That said, it cannot be denied that in all three emirates standard buildings are still quite large and consume vast amounts of resources, water and energy, compared to international standards. Moreover, users and residents are gently encouraged to scale down their consumption rates rather than being legally obliged to do so: the carrot and the sermon are used instead of the stick. 
As we can see in Table 5, when it comes to the developmental of new smart and sustainable residential areas, the emerging picture is much in line with what we saw for urban spaces promoting economic diversification and world-class innovation: Qatar and Abu Dhabi put most of their cards on a small number of very large project areas, while Dubai develops a higher number of smaller ones.

Abu Dhabi clearly boasts the globally best-known prestige smart city project: Masdar City. Likewise, in Qatar, Lusail Smart City is under development. Both mega urban development projects do not feature prominently in the official master plans, but their presence is very pronounced in online promotion videos and leaflets. Among the two, Masdar emerged earlier than Lusail; it was originally introduced as the first zero carbon city worldwide and later acquired a number of smart city features. Its general profile, however, still leans more on the creation of new green energy technologies and sustainable architectural features ('sustainable city') than on ICT and data processing. Lusail Smart City, on the other hand, is the essential interpretation of an Internet of Things style urban area where in a central command and operations centre incoming information taken from sensors all around the city is processed and acted upon. The smart city is part of the broader Lusail municipality expansion by the coast 23 kilometres north of Doha to accommodate the World Cup Football in 2022. Both Masdar and Lusail are generously funded by national investment corporations; subsidies and loans run in the billions of dollars. Disturbingly, it appears that progress for both of these mega-projects has slowed down and that ambition levels have been lowered, in spite of their impressive reputation among the uninitiated. In Masdar City, for instance, the personal rapid transit system never went beyond the testing stage, only the buildings constructed in the early stages are covered with solar panels and the exhibition hall shows few significant achievements in later years. In a similar vein, the optimism about Lusail Smart City has disappeared. It is in fact the much more small-scale and less actively branded Msheireb Downtown Doha (MDD) project that is gaining recognition. In MDD, data analytics is applied to a variety of sustainability aspects, such as the preservation of cultural heritage, transport systems and energy saving. Concerning the latter, data are collected and analysed on energy production and consumption, and use for awareness raising, enhancing energy efficiency and the smart metering of utilities. Notably, Dubai does not have prestigious smart or sustainable city projects boosted with similarly huge amount of investments, but it instead has a variety of more modest ones. Among them the Sustainable City, a mixed-use car-free township filled with 10,000 trees and organic farms with energy produced from solar parks, sustainable appliances installed in people's homes and various other features offering a low carbon lifestyle, is best known. Desert Rose City, with approximately 20,000 private residential units of the City for Emirati citizens and 10,000 for expatriates, was named after its shape. It runs on renewable energy produced in the city itself and is provided with a waste recycling facility. Dubai's South District, the location of the Expo 2020 site, has planned to have half of the electricity used in this event coming from renewable sources on the site and to reuse more than half of the material used in the construction of the site in future infrastructures. Finally, Smart Dubai is an emirate-wide data platform with a growing number of applications to the measurement and improvement of Dubai government services. Its main objective is to make inhabitants 'happy' through an improved quality of life. Smart Dubai is different from the others in the sense that it is not restricted to any specific urban space and therefore not an urban development project strictly speaking. 
Table 5. Smart and sustainable cities and their key features in Qatar, Abu Dhabi and Dubai.

\begin{tabular}{|c|c|c|c|c|c|}
\hline & Name & Profile/Brand & Area/Location & $\begin{array}{l}\text { Investment/Source of } \\
\text { Funding }\end{array}$ & key Features \\
\hline \multirow[t]{4}{*}{ Dubai } & Dubai Smart City & $\begin{array}{l}\text { The first happiest smart city in } \\
\text { the world }\end{array}$ & Dubai land & Governmental & $\begin{array}{l}\text { Renewable Energy } \\
\text { Electric vehicles (EVs) } \\
\text { Paperless government } \\
\text { Smart Health } \\
\text { Sustainability } \\
\text { Green building regulation }\end{array}$ \\
\hline & Dubai Sustainable City & A sustainable lifestyle & $\begin{array}{l}460000 \text { sq. m/next to } \\
\text { Dubai Studio City }\end{array}$ & $\begin{array}{l}\text { Private funding (Diamond } \\
\text { Developers) }\end{array}$ & $\begin{array}{l}\text { Sustainable life style } \\
\text { Eco system services (eco system for birds, productive land with date palms, farms) } \\
\text { walkability } \\
\text { Innovation center } \\
\text { Green building regulation }\end{array}$ \\
\hline & $\begin{array}{l}\text { 'Desert Rose' } \\
\text { Smart Sustainable City }\end{array}$ & $\begin{array}{l}\text { A flower shaped } \\
\text { environment-friendly city }\end{array}$ & $\begin{array}{l}40 \text { sq. } \mathrm{km} / \mathrm{a} \text { desert land at } \\
\text { Dubai urban fringe }\end{array}$ & Dubai Municipality & $\begin{array}{l}\text { Eco walk } \\
\text { Indicative accessibility (pedestrian and cyclists, light-rail, roads) } \\
\text { District Cooling } \\
\text { Vacuum Solid Waste Network } \\
\text { Multi-Utilities Tunnels Network } \\
\text { Electrical Network } \\
\text { Solar roofs \& turbines }\end{array}$ \\
\hline & Dubai South & $\begin{array}{l}\text { The city of you- A city that } \\
\text { defines itself by happiness of } \\
\text { the individuals }\end{array}$ & $\begin{array}{l}145 \mathrm{sq} . \mathrm{km} / \mathrm{next} \text { to Jebel } \\
\text { Ali free zone }\end{array}$ & Governmental & $\begin{array}{l}\text { The lieu of Expo } 2020 \\
\text { Renewable energy } \\
\text { Self-sustained urban destination to empower businesses, families and individuals } \\
\text { to grow and prosper }\end{array}$ \\
\hline Abu Dhabi & Masdar City & $\begin{array}{l}\text { A sustainable destination for } \\
\text { residents and visitors to live, } \\
\text { work, play and learn }\end{array}$ & $\begin{array}{l}6 \text { sq. km/beside Abu } \\
\text { Dhabi International } \\
\text { Airport }\end{array}$ & $\begin{array}{l}\text { Mubadala Development } \\
\text { Company }\end{array}$ & $\begin{array}{l}\text { Clean Energy (Photovoltaic Power, Concentrated Solar Power, Wind, } \\
\text { Waste-to-Energy, Energy Storage) } \\
\text { Sustainability } \\
\text { Eco-Villa prototype } \\
\text { Mobility (driverless Personal Rapid Transit) } \\
\text { Green building regulation }\end{array}$ \\
\hline \multirow{2}{*}{ Qatar } & Lusail & A city with a vision & $\begin{array}{l}38 \mathrm{sq} . \mathrm{km} / \mathrm{located} \text { on the } \\
\text { coast, about } 23 \mathrm{~km} \text { north } \\
\text { of the city center of Doha }\end{array}$ & $\begin{array}{l}\text { Qatari Diar Real Estate } \\
\text { Investment Company }\end{array}$ & $\begin{array}{l}\text { Eco Friendly Alternatives } \\
\text { Mobility (light rail transportation, Water transport system, Cycle and Pedestrian } \\
\text { Ways System, Road hierarchy System) } \\
\text { Sustainable Infrastructures (District Cooling, Pneumatic Waste Collection, Sewage } \\
\text { Treatment Plant) } \\
\text { Building rating (Gulf Sustainability Assessment System) }\end{array}$ \\
\hline & MSHEIREB & $\begin{array}{l}\text { Envisioning the city of the } \\
\text { future }\end{array}$ & $\begin{array}{l}764000 \text { sq. } \mathrm{m} / \text { Downtown } \\
\text { Doha }\end{array}$ & $\begin{array}{l}\text { Msheireb Properties (a } \\
\text { subsidiary of Qatar } \\
\text { Foundation) }\end{array}$ & $\begin{array}{l}\text { Place Making and green building } \\
\text { Walkability, Mixed Uses } \\
\text { Authenticity } \\
\text { Sustainability } \\
\text { Mobility }\end{array}$ \\
\hline
\end{tabular}




\section{Results of the Analysis}

Rentier states have generally been characterised as nations with governments that can rely on impressive amounts of revenue derived from their natural resources to keep their populations happy and themselves firmly in power. Some of these smaller rentier states have managed to convert their economic gain into reputation gain: they reached world fame at breakneck speed through impressive place branding activities. This why Qatar, Abu Dhabi and Dubai are now well-known around the world despite their small size and limited population size. In recent years, the era of post-oil and climate change has confronted them with a new and potentially even greater challenge: can they repeat the trick but then in terms of making an ecological miracle happen after having already created an economic one, and use their branding skills in a similar way to do this?

One of the areas where such a major environmental achievement is due is sustainable urbanisation. Major investments are made in developing new industrial and trade zones that go beyond oil and gas exploration and exploitation alone, in research and education cities where high-tech innovation is bred for future generations to lean on and in liveable and smart residential areas where residents may dwell in comfortable and ecologically friendly ways. In Sections 4 and 5, we have shown that the skillful approach Qatar, Abu Dhabi and Dubai developed in branding themselves as economically and financially successful places has indeed been replicated and possibly even further enhanced in coming across as being fully engaged in smart and sustainable urban development. This is visible both in their glossy and enthusing national visions and planning frameworks and in the urban development projects they engage in and promote globally through various channels.

The manner in which this was done, nevertheless, shows a remarkable difference between the larger and more conservative Qatar and Abu Dhabi on the one hand, and the more liberal Dubai on the other. Qatar and Abu Dhabi tend to initiate smaller numbers of far larger projects funded primarily by their national governments and/or large national investment corporations with dominant involvement of the national leadership. These mega-projects are widely touted as being cutting edge and have obtained global renown as being at the forefront of technological and urbanistic development. Education City in Qatar and Masdar City in Abu Dhabi are the most conspicuous examples of this. Abu Dhabi's Masdar City plays three roles at the same time: a free economic zone, home to a world-class research institute and a prestigious sustainable city. Qatar's Education was originally just set up for academic purposes, but recently pockets of it have been reserved as Free Trade Zones as well. This leads to conglomerate spaces where various functions are served at the same time. Conversely, Dubai has initiated a much larger number of relatively smaller urban development projects: it has more free economic zones, more foreign universities and more smart or sustainable urban neighbourhoods in its territory than the other two combined, although most of them do not exceed the size of just 1 square kilometer and they are all located at different sites. Much of the funding comes from private sources or is least mixed public-private in nature (although this certainly does not preclude Royal Family involvement). Dubai's branding capabilities are not inferior to those in Qatar and Abu Dhabi: its Media City, Internet City, Sustainable City and Smart Dubai have received or are beginning to receive wide international acclaim too. In other words, sustainable urbanisation in its various facets ranks highly on the policy agenda of all three emirates in the present study. All three have extensively engaged in place branding to boost their respective urban development initiatives derived from this policy agenda and all three have actually undertaken action to establish such smart and sustainable places. But there, the similarities end. An overview of key findings of our analysis is presented in Table 6. 
Table 6. Summary table with key findings.

\begin{tabular}{cccccc}
\hline Emirate & Rentier State & $\begin{array}{c}\text { Active Place } \\
\text { Branding }\end{array}$ & Free Economic Zones & Education/Academic Cities & $\begin{array}{c}\text { Smart/Sustainable } \\
\text { Residential Areas }\end{array}$ \\
\hline Qatar & Yes (gas) & Yes & Small number of large ones & Small number of leading universities & One large project \\
Abu Dhabi & Yes (oil) & Yes & Small number of large ones & $\begin{array}{c}\text { Small number of leading universities } \\
\text { Large number of middle-of-the-road }\end{array}$ & One large project \\
Dubai & Not any more & Yes & Large number of small ones & $\begin{array}{c}\text { Several smaller projects } \\
\text { unities }\end{array}$ & \\
\hline
\end{tabular}

Qatar and Abu Dhabi can both still rely on huge amounts of natural gas and oil, respectively, and may well continue to have sufficient reserves of these resources for decades to come. The post-oil policy is mostly a matter of preparing for climate change and a good reputation in handling international responsibilities. There is pressure to transform, but this pressure is primarily non-economic and therefore not directly felt by its governments and residents. In that sense, both emirates are still typical rentier states. Seen from that angle, it is unsurprising that their economic diversification is far from complete, that the intellectual output from their education and high tech areas (especially among Emirati and Qatari) is mediocre and that their smart and sustainable cities resemble modern versions of the 'technopoles' as described by Castells and Hall [57]. While Qatar has a stronger focus on promoting SMEs in light industrial sectors and Abu Dhabi on larger corporations in heavy manufacturing industry, in both cases their total economic weight is limited and the environmental gain of having them in place questionable. Moreover, their supply-driven approach has led to disappointing interest among private and international developers. Functionally they are less smart and sustainable than many would have wished. Their governments may well have the financial means to build facilities and places for the new age and change aspects of the production system, but they make this attempt in the absence of strict regulations which can be enforced. This becomes even more visible in the urging of their locals to conserve natural resources, like energy and water: this is all highly unpopular and mostly left to people's free will. Economic incentives are not administered, or rather they favour a lavish, rather than economical use of resources, and the political odds are likely to remain for some time to come. In this system, the branding of sustainable urbanisation is more sophisticated than the policy action itself can be, and being or having in place a rentier state lends much credibility to the argument that this context is notoriously difficult to change. Becoming smart and sustainable in action rather than words is tough if there is no physical or economic necessity to do so.

The story of Dubai is different. Its having depleted the lion's share of its natural resources has effectively made it an ex rentier state. Following the logic of Davidson's (2012) mechanisms for political stability and change, we might have predicted an imminent regime shift [15]. However, no such thing has occurred yet, and there are few if any signs of this being in the offing. What has in fact happened thus far is that the Dubai leadership encouraged a much more thorough economic transition by offering a great variety of differently tagged enclaved spaces all aimed at attracting different types of business sectors, educational audiences and residential target groups. Its urban expansion is far more pervasive and less selective than that of Qatar and Abu Dhabi and aims to offer different things to different corporations and inhabitants in different enclaves. A greater share of the investments is funded from private sources and there are many more free economic zones, academic institutes and smart and/or sustainable neighbourhoods, each of a smaller scale and less exclusive.

Given a higher level of dependence on private sector and international investors and settlers, the demand orientation in Dubai is more pronounced and the result is a better match with the needs of its intended clients. We should qualify this positive economic assessment to the extent that Dubai had to be saved from bankruptcy by Abu Dhabi in the aftermath of the financial crisis and therefore received external support. Its economic diversification has clearly been much more successful, but not all of it is top-notch. There is enormous variation in foreign academic institutes to choose from, but all of them are medium-range, private and expensive. And likewise, there are many profiles of differently styled residential areas and a small number of them reveal a serious attempt to create sustainable lifestyles. However, since many more others are built at the same time that offer impressive villas inviting high consumption levels without ecological features, the net environmental gain is 
limited. This practice in sustainable urbanisation allows for Dubai to appear as the number 1 on key performance indicators such as the fast rise in service oriented economic activity, number of foreign universities in its midst and presence of green buildings in its territory, while keeping its ecological footprint at unprecedented levels and almost on a par with Qatar and Abu Dhabi.

That said, Dubai is recognised by representatives from other emirates as being leader in taking steps to save energy and being serious about green building regulations. If anything dynamic towards sustainability will happen, it is most likely to be there. Transformative intentions in ex rentier states may indeed land on more fertile soil than in states still replete with gas and oil reserves. At the same time, it is tempting ultimately to draw the conclusion that from an environmental point of view, smart-sustainable urban forms in Qatar, Abu Dhabi and Dubai can be perceived as a 'branding hoax' [58]: their economic success is undeniable and the institutional mechanisms for growth and expansion operate as strongly as before, but the proclaimed ecological miracle at an aggregate level remains just a promise.

For their permanence, regimes in rentier states as well as ex rentier states seem to depend on continued economic success. Qatar, Abu Dhabi and Dubai have all three done a truly impressive job in redirecting financial revenues derived from their natural resources in sophisticated ways. All three have used advanced place branding strategies to achieve this, with Dubai having largely completed its industrial transition already since circumstances forced it to do so. The regime and leadership enjoy broad support and there are few indications that this will change any time soon. But successful recipes for dramatic industrial growth and urban expansion are unlikely bedfellows for reducing consumption rates of materials, water and energy, also when they go by the attractive name 'sustainable urbanisation'.

\section{Conclusions and Discussion}

This paper set out to answer two research questions:

1. Which steps have been taken to substantiate Qatar, Abu Dhabi and Dubai's claims to economic and ecological modernization?

2. Is there a difference in this between rentier states (Abu Dhabi and Qatar) and former rentier states (Dubai)?

Regarding the first question, steps undertaken to achieve economic and ecological modernization regimes seem to depend on continued economic success. Strategic policies in Qatar, Abu Dhabi and Dubai that aim at preparing for a post-oil economy are characterized by a diversification of their industrial activities and a preservation of their natural environment. All three have all three have indeed managed to redirect financial revenues and succeeded in in branding themselves as economically and financially successful places, for smart and sustainable urban development, as can be seen in their glossy and enthusing national visions and planning frameworks and the large-scale urban development projects they engage in.

Concerning the second question, we found a clear distinction between current rentier states Abu Dhabi and Qatar on the one hand, and semi-rentier state Dubai on the other. Whereas the former can still rely on the availability of oil and natural gas, the latter cannot and has been urged to cope with this new situation. However, it managed to do so through creating policies to diversify its economy and remain an attractive space in the region. It also led Dubai increasingly to differentiate itself economically from Abu Dhabi and Qatar, such as by going for quantity, variety and a demand orientation rather than prestige, selectiveness and a supply-driven approach. It now has a large number of relatively small free economic zones (instead a small number of large ones), a large number of average universities (instead of a few top universities), and a large number of sustainability projects (instead of one world famous sustainability project). Qatar and Abu Dhabi did the exact opposite.

All three emirates did their share of branding, but semi-rentier state Dubai truly excelled in this endeavour. It also managed to largely complete its industrial transition; circumstances forced it to do 
so. Their regime and leadership continue to enjoy broad support and there are few indications that this will change any time soon. This does not imply that successful recipes for dramatic industrial growth and urban expansion go hand in hand with lower rates of consumption. Sustainable urbanisation is clearly more an economic than an ecological success, and therefore it cannot be claimed that the environmental part of the branding promise is kept.

\subsection{Discussion}

Unlike worries or predictions made by authors like Davidson $(2008,2012)$, Coates Ulrichsen (2011, 2017), and Luomi (2012) no serious regime shift in any of the three emirates has been witnessed so far. Nor does radical political change seem nigh. As for Qatar and Abu Dhabi, one may claim that no such turbulence could have been expected, given the fact that their oil and gas reserves are vast enough to carry on with lucrative exploitation for many decades ahead. This situation continues to allow them to buy the support of their citizens through generous policies. In the case of Dubai, the Monarchy and elite families around it have shown strong economic leadership and orchestrated industrial, knowledge and industrial transformation without even coming close to being under threat. With regard to Luomi's earlier observations (2012) about a proclaimed policy shift in the emirates made in response to negative aspects in their global image in environmental affairs and the leading role Abu Dhabi was found to play in turning this around through active attempts towards an energy transformation, the present study shows that all three emirates are now engaged in formulating ambitious policies to foster sustainable urban development. However, the branding of these policies is decidedly more effective than their implementation. Moreover, while the excitement about Masdar City appears largely to have died down, it is Dubai that has taken thfe lead in many fields and referred to as a model to follow with its various themed cities, its relatively stricter building regulations and its Sustainable City which is planned to be replicated in the nearby emirate of Sharjah. Vis-à-vis the set of objectives city branding strategies can have according to Shirvani Dastgerdi and Di Luca (2019) we observed that the focus city branding strategies Qatar, Abu Dhabi and Dubai have is on creating global uniqueness, attracting resources, and arguably wellbeing of citizens (although about them, without them) but to a lesser extent on other types of objectives like meaningfulness and acceptability, justifiable identity, and involving stakeholders [36].

In sum, it is fair to state that a pro-claimed shift has been achieved and secured in policy making by reducing petroleum-related activities and establishing alternative industries (admittedly not all of them clean) by setting first steps in the development of a knowledge economy and by developing signature smart and sustainable residential areas. However, this has not (yet) really resulted in mitigating the environmentally harmful consequences of the extremely generous production and consumption patterns in either of the three emirates. Critics may well claim that the impactful branding of their environmental policies and landmark development projects should actually be seen as advanced forms of greenwashing. Nor do they reflect forms of active domestic stakeholder involvement that may trigger more thorough socio-cultural transformation. In that sense, the observations made in the present study are in line with some of the criticism vented by Cugurullo $(2013,2016)$ on the policy strategies looming behind Masdar City [41,59]. Similar remarks, mutatis mutandis, could also be raised with respect to Lusail City and other mega-projects in the emirates. Building an effective sustainable and/or smart city required a holistic approach across various technologies, policy areas and stakeholders which is often complicated to realise [60].

\subsection{Limitations of This Study and Suggestions for Further Research}

Limitations to the study mostly pertain to case selection and data collection. Regarding case selection only three particular cases in the Middle East were analysed. Although they are very significant examples of rentier states, the outcomes here beg the question whether using a wider set of cases for our analysis, and perhaps even cases of emirates that never were rentier states, would have led to other results. For instance, would the absence of sophisticated branding or convincing leadership 
have led to different outcomes? Assuming that valid data can be retrieved (which at the time of writing still seems doubtful here and there), taking the other emirates within the UAE, Bahrain, Kuwait and cities within other Middle Eastern states would offer insight in what the results of variations in the scores for various variables types of (ex) rentier states, (un)sophisticated branding strategies and (in)effective policy implementation, pro-active or reactive leadership) would lead to. Online data collection in Qatar, Abu Dhabi and Dubai proceeded smoother than it would have in many places elsewhere, but obtaining interviews was sometimes less straightforward. Eventually we were able to interview a number of civil servants, business employees and academic experts, but no interviews were conducted with either leaders, officials or citizens. This may have biased the findings in our work to a certain extent. Nonetheless, we feel that in this contribution, a bridge was built between concepts derived from political science on small Arab monarchies and policy practices in sustainable urbanisation. Few if any such efforts to collect empirical evidence of this connection have previously been made. Future studies could address shortcomings of the present study and build on its findings. They could also take up the challenge of more critically addressing and weighing the actual long-term environmental benefits of the developmental strategies chosen by the emirates. Moreover, they could examine the political and administrative processes underlying policy changes and the roles various stakeholders play in them.

Author Contributions: M.D.J. wrote most of the article and is the main author, data collection has been done by all, guided by N.N. and analyzed by all. Final editorial work has been done by T.H.

Funding: This research was funded by The Netherlands Organization for Scientific Research (NWO), with project number 467-14-153.

Acknowledgments: The authors are indebted to Zakaria el Khelloufi and Zakaria Mohamed for their support in the data collection. They are also grateful to Mustapha Aanzi and Tim Rogmans for introducing us to many of the respondents and to Christopher Davidson and Aziza Mayar for comments on an earlier version of this paper.

Conflicts of Interest: The authors declare no conflict of interest.

\section{References}

1. Davidson, C. (Ed.) Power and Politics in the Persian Gulf Monarchies; Hurst \& Company: London, UK, 2011.

2. Fromherz, A.J. Qatar: A Modern History; Georgetown University Press: Washington, DC, USA, 2017.

3. Coates Ulrichsen, K. The United Arab Emirates: Power, Politics and Policymaking; Routledge: London, UK, 2017.

4. Davidson, C. Dubai: The Vulnerability of Success; Hurst \& Company: London, UK, 2008.

5. Davidson, C. Abu Dhabi: Oil and Beyond; Hurst \& Company: London, UK, 2009.

6. Kamrava, M. Qatar: Small State, Big Politics; Cornell University Press: Ithaca, NY, USA, 2013.

7. Roberts, D.B. Qatar: Securing the Global Ambitions of a City-State; Hurst \& Company: London, UK, 2017.

8. Commins, D. The Gulf States: A Modern History; I.B. Tauris: London, UK, 2012.

9. Syed, A. Dubai: Guilded Cage; Yale University Press: New Haven, CT, USA, 2010.

10. Luomi, M. The Gulf Monarchies and Climate Change: Abu Dhabi and Qatar in an Era of Natural Unsustainability; Hurst \& Company: London, UK, 2012.

11. Tok, E.; Al Mohammad, F.; Al Merekhi, M. Crafting smart cities in the gulf region: A comparison of Masdar and Lusail. Eur. Sci. J. 2014, 2, 1857-1881.

12. Dinnie, K. (Ed.) City Branding: Theory and Cases; Palgrave Macmillan: Basingstoke, UK, 2011.

13. Govers, R.; Go, F. Place Branding: Glocal, Virtual and Physical Identities, Constructed, Imagined and Experienced; Palgrave Macmillan: Basingstoke, UK, 2009.

14. Westwood, S. Branding a 'new' destination: Abu Dhabi. In Destination Brands: Managing Place Reputation; Nigel, M., Pritchard, A., Pride, R., Eds.; Routledge: London, UK, 2011.

15. Davidson, C. After the Sheikhs: The Coming Collapse of the Gulf Monarchies; Hurst \& Company: London, UK, 2012.

16. Coates Ulrichsen, K. Qatar and the Arab Spring; Hurst \& Company: London, UK, 2014.

17. World Bank. United Arab Emirates. 2019. Available online: https://data.worldbank.org (accessed on 15 March 2019). 
18. Coates Ulrichsen, K. Insecure Gulf: The End of Certainty and the Transition to the Post-Oil Era; Hurst \& Company: London, UK, 2011.

19. Krane, J. Dubaiu: The Story of the World's Fastest City; Atlantic Books: London, UK, 2015.

20. Kazerouni, A. Le Miroir des Cheikhs; Musee et Politique dans les Principautes du Golfe Persique; Presses Universitaires de France: Paris, France, 2017.

21. Makadam, S.; Ramaswamy, R. Sustainable smart city: Masdar (UAE) (A City: Ecologically Balanced). Indian J. Sci. Technol. 2014, 9. [CrossRef]

22. Al Naimi, A.; Karani, G.; Littlewood, J. Stakeholder Views on Land Reclamation and Marine Environment in Doha, Qatar. J. Agric. Environ. Sci. 2018, 7, 32-39.

23. Angelidou, M. Smart city planning and development shortcomings. TeMA. J. Land Usemobil. Environ. 2017, 10, 77-94.

24. Goess, S.; de Jong, M.; Meijers, E. City branding in polycentric urban regions: Identification, profiling and transformation in the Randstad and Rhine-Ruhr. Eur. Plan. Stud. 2016, 24, 2036-2056. [CrossRef]

25. De Jong, M.; Chen, Y.; Joss, S.; Lu, H.; Zhao, M.; Yang, Q.; Zhang, C. Explaining city branding practices in China's three mega-city regions: The role of ecological modernization. J. Clean. Prod. 2018, 179, 527-543. [CrossRef]

26. Noori, N.; de Jong, M. Towards Credible City Branding Practices: How Do Iran's Largest Cities Face Ecological Modernization? Sustainability 2018, 10, 1354. [CrossRef]

27. Baker, B. Destination Branding for Small Cities, 2nd ed.; Creative Leap Books: Portland, OR, USA, 2012.

28. Hankinson, G. Place branding research: A cross-disciplinary agenda and the views of practitioners. Place Branding Public Dipl. 2010, 6, 300-315. [CrossRef]

29. Zenker, S.; Braun, E.; Petersen, S. Branding the destination versus the place: The effects of brand complexity and identification for residents and visitors. Tour. Manag. 2017, 58, 15-27. [CrossRef]

30. Boisen, M.; Terlouw, K.; Groote, P.; Couwenberg, O. Reframing place promotion, place marketing, and place branding-Moving beyond conceptual confusion. Cities 2017, 80, 4-11. [CrossRef]

31. Lu, H.; de Jong, M.; Chen, Y. Economic city branding in China: The multi-level governance of municipal self-promotion in the Greater Pearl River Delta. Sustainability 2017, 9, 496. [CrossRef]

32. Kavaratzis, M. From city marketing to city branding: Towards a theoretical framework for developing city brands. Place Branding 2004, 1, 58-73. [CrossRef]

33. Kavaratzis, M.; Ashworth, G. City branding: An effective assertion of identity or a transitory marketing trick? Ahmadreza Shirvani Dastgerdi Giuseppe De Luca Geographica Pannonica 2005, 96, 506-514. [CrossRef]

34. Baker, B. Destination Branding for Small Cities: The Essentials for Successful Place Branding; Destination Branding Book: Portland, OR, USA, 2007.

35. Anholt, S. Places: Identity, Image and Reputation; Springer: Basingstoke, UK, 2016.

36. Shirvani-Dastgerdi, A.; De-Luca, G. Boosting city image for creation of a certain city brand. Geogr. Pannonica 2019, 23, 23-31. [CrossRef]

37. Hudson, S.; Cárdenas, D.; Meng, F.; Thal, K. Building a place brand from the bottom up: A case study from the United States. J. Vacat. Mark. 2017, 23, 365-377. [CrossRef]

38. Kavaratzis, M.; Kalandides, A. Rethinking the place brand: The interactive formation of place brands and the role of participatory place branding. Environ. Plan. A 2015, 47, 1368-1382. [CrossRef]

39. Pedeliento, G.; Kavaratzis, M. Bridging the gap between culture, identity and image: A structurationist conceptualization of place brands and place branding. J. Prod. Brand Manag. 2019. [CrossRef]

40. Al Madani, S. LinkedIn Profile. Available online: https://ae.linkedin.com/in/dr-sara-al-madani-b4b84722 (accessed on 30 April 2019).

41. Cugurullo, F. Building a sand castle: An analysis of the genesis and development of Masdar City. J. Urban Technol. 2013, 20, 23-37. [CrossRef]

42. Yin, R. Case Study Research: Design and Methods; Sage Publications: Los Angeles, CA, USA, 2003.

43. Gerring, J. Qualitative Methods. Annu. Rev. Political Sci. 2017, 20, 15-36. [CrossRef]

44. Mahdavy, H. The Pattern and Problems of Economic Development in Rentier States: The Case of Iran. In Studies in the Economic History of the Middle East; Oxford University Press: Oxford, UK, 1970.

45. Government.ae. Plans and Initiatives for Sustainable Transportation. 1 July 2018. Available online: https://go vernment.ae/en/information-and-services/education/importance-of-education-to-the-government (accessed on 30 February 2019). 
46. Qatar National Development Strategy 2011 2016; Qatar General Secretariat for Development Planning: Doha, Qatar, 2016.

47. Qatar Higher Authorities. Qatar National Vision 2030. 2008, pp. 1-19. Available online: http://tinyurl.com/ ha6fbgc (accessed on 30 February 2019).

48. Arcadis. Dubai, Abu Dhabi and Doha Are the Region's Most Sustainable Cities, Says New Index. 10 February 2015. Available online: https://www.arcadis.com/en/middle-east/news/latest-news/2015/2/dubaiabu-dhabiand-doha-are-the-region-s-most-sustainable-citiessays-new-index (accessed on 15 April 2019).

49. DEWA. Dubai Green Building Regulations \& Specifications; Government of Dubai: Dubai, UAE, 2013. Available online: https://www.dewa.gov.ae/en/consultants-and-contractors/policies-and-regulations/circulars-andforms/green-building (accessed on 25 May 2018).

50. Dubai Government. Dubai Industrial Strategy 2030. 10 February 2015. Available online: https://www.duba iplan2021.ae//wp-content/uploads/2016/06/Dubai-Industrial-Strategy-2030.pdf (accessed on 20 May 2018).

51. Government of United Arab Emirates. Annual Economic Report. 27 January 2017. Available online: http://ww w.economy.gov.ae/EconomicalReportsEn/MOEAnnualReport2017_English.pdf (accessed on 15 April 2019).

52. Government.ae. Dubai. 1 July 2018. Available online: https:/government.ae/en/information-and-services/ed ucation/importance-of-education-to-the-government (accessed on 1 July 2018).

53. Government.ae. Dubai Clean Energy Strategy. 1 July 2018. Available online: https://government.ae/en/infor mation-and-services/education/importance-of-education-to-the-government (accessed on 1 July 2018).

54. Qatar Education and Training. 4 May 2018; In www.export.gov. Available online: https://www.export.gov/a rticle?id=Qatar-Education-and-Training (accessed on 04 May 2018).

55. Hazem Shayah, M.; Qifeng, Y. Development of Free Zones in United Arab Emirates. Int. Rev. Res. Emerg. Mark. Glob. Econ. 2015, 2, 286-294.

56. Qatar Green Building Council. QGBC \& QNV 2030. 2018. Available online: https://qatargbc.org/aboutus/q gbc-qnv2030 (accessed on 15 May 2018).

57. Castells, M.; Hall, P. Technopoles of the World: Making of 21st-Century Industrial Complexes; Routledge: London, UK, 1994.

58. Yigitcanlar, T.; Lee, S.H. Korean ubiquitous eco-city: A smart-sustainable form or a branding hoax. Technol. Forecast. Soc. Chang. 2014, 89, 100-114. [CrossRef]

59. Cugurullo, F. Urban eco-modernisation and the policy context of new eco-city projects: Where Masdar City fails and why. Urban Stud. 2016, 53, 2417-2433. [CrossRef]

60. Yigitcanlar, T. Smart cities: An effective urban development and management model? Aust. Plan. 2015, 52, 27-34. [CrossRef]

(C) 2019 by the authors. Licensee MDPI, Basel, Switzerland. This article is an open access article distributed under the terms and conditions of the Creative Commons Attribution (CC BY) license (http://creativecommons.org/licenses/by/4.0/). 